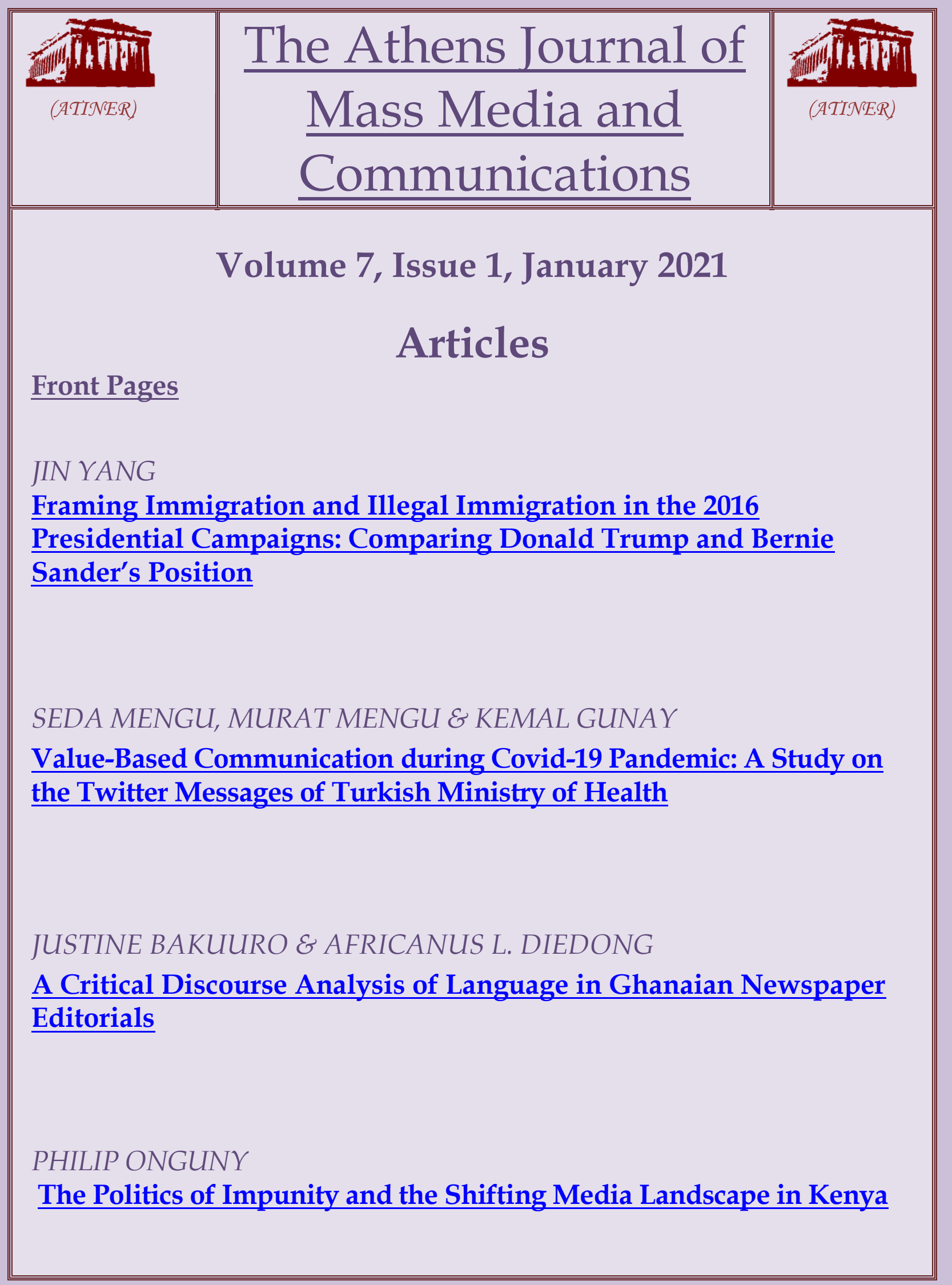




\section{Mission}

ATINER is an Athens-based World Association of Academics and Researchers based in Athens. ATINER is an independent and non-profit Association with a Mission to become a forum where Academics and Researchers from all over the world can meet in Athens, exchange ideas on their research and discuss future developments in their disciplines, as well as engage with professionals from other fields. Athens was chosen because of its long history of academic gatherings, which go back thousands of years to Plato's Academy and Aristotle's Lyceum. Both these historic places are within walking distance from ATINER's downtown offices. Since antiquity, Athens was an open city. In the words of Pericles, Athens"... is open to the world, we never expel a foreigner from learning or seeing". ("Pericles' Funeral Oration", in Thucydides, The History of the Peloponnesian War). It is ATINER's mission to revive the glory of Ancient Athens by inviting the World Academic Community to the city, to learn from each other in an environment of freedom and respect for other people's opinions and beliefs. After all, the free expression of one's opinion formed the basis for the development of democracy, and Athens was its cradle. As it turned out, the Golden Age of Athens was in fact, the Golden Age of the Western Civilization. Education and (Re)searching for the 'truth' are the pillars of any free (democratic) society. This is the reason why Education and Research are the two core words in ATINER's name. 
The Athens Journal of Mass Media and

Communications

ISSN NUMBER: 2407-9677 - DOI: 10.30958/ajmmc

Volume 7, Issue 1, January 2021

Download the entire issue ( $\underline{\mathrm{PDF}})$

$\underline{\text { Front Pages }}$

Framing Immigration and Illegal Immigration in the

2016 Presidential Campaigns: Comparing Donald

Trump and Bernie Sander's Position

Jin Yang

Value-Based Communication during Covid-19

Pandemic: A Study on the Twitter Messages of Turkish Ministry of Health

Seda Mengu, Murat Mengu E Kemal Gunay

A Critical Discourse Analysis of Language in

Ghanaian Newspaper Editorials

Justine Bakuuro \& Africanus L. Diedong

The Politics of Impunity and the Shifting Media

61

Landscape in Kenya

Philip Onguny 


\section{The Athens Journal of Mass Media and Communications Editorial and Reviewers' Board}

$\underline{\text { Editors }}$

- Dr. John Pavlik, Head, Mass Media and Communication Unit, ATINER \& Professor, Journalism and Media Studies, School of Communication and Information, Rutgers University, USA.

- Dr. Yorgo Pasadeos, Director, Social Sciences Division, ATINER \& Professor Emeritus, University of Alabama USA.

- Dr. Patrick Vyncke, Professor of Communication Management, Department of Communication Sciences, Ghent University, Belgium.

\section{Editorial Board}

- Dr. John Pavlik, Head, Mass Media and Communication Unit, ATINER \& Professor, Rutgers University, USA.

- Dr. Burak Dogu, Academic Member, ATINER \& Vice Dean, Izmir University of Economics, Turkey.

- Dr. Andzela Armoniene, Head of The Fund Young Researcher, Lithuania.

- Dr. Mariam Gersamia, Professor \& Head, Division of Journalism and Mass Communication, Ivane Javakhishvili Tbilisi State University, Georgia.

- Dr. Egle Jaskuniene, Associate Professor \& Vice Dean for Research, Faculty of Creative Industries, Vilnius Gediminas Technical University, Lithuania.

- Dr. Berrin Yanikkaya, Academic Member, ATINER and Professor \& Head, School of Communication Studies, Auckland University of Technology, New Zealand.

- Dr. Dali Osepashvili, Professor, Department of Journalism and Mass Communication, Ivane Javakhishvili Tbilisi State University, Georgia.

- Dr. Walter Wymer, Academic Member, ATINER \& Professor of Marketing, University of Lethbridge, Canada.

- Dr. Alan Albarran, Academic Member, ATINER \& Professor, The University of North Texas, USA.

- Dr. Patricia L. Dooley, Elliott Distinguished Professor of Communication, Wichita State University, USA.

- Dr. Catherine Ann Collins, Professor, Department of Rhetoric, Willamette University, USA.

- Dr. Pamela Doyle Tran, Professor of Electronic News, University of Alabama, USA.

- Dr. S. Andrews, Professor, Department of Information Technology, Mahendra Engineering College, India.

- Dr. Emmanuel Ngwainmbi, Department of Communication Studies, The University of North Carolina, USA.

- Dr. Zsolt Alfred Polgar, Academic Member, ATINER \& Associate Professor, 
Technical University of Cluj-Napoca, Romania.

- Dr. Margaret M. Cassidy, Academic Member, ATINER \& Associate Professor, Adelphi University, USA.

- Dr. Baris Coban, Associate Professor, Communication Sciences Department, Dogus University, Turkey.

- Dr. Ulas Basar Gezgin, Associate Professor of Applied Communication, British University Vietnam, Vietnam.

- Dr. Anya Luscombe, Associate Professor and Head, Department of Academic Core, University College Roosevelt, The Netherlands.

- Dr. Charles Obot, Academic Member, ATINER \& Associate Professor, University of Uyo, Nigeria.

- Dr. Ceren Sozeri, Associate Professor, Faculty of Communication, Galatasaray University, Turkey.

- Dr. Matthew D. Matsaganis, Assistant Professor, Department of Communication, State University of New York (SUNY), USA.

- Dr. Geneviève A. Bonin, Assistant Professor, University of Ottawa, Canada.

- Dr. Klarissa Lueg, Assistant Professor, Aarhus University, Denmark.

- Dr. George Pavlou, Assistant Professor, European University, Cyprus.

- Dr. Yolandi Slabbert, Senior Lecturer, Department of Communication Science, University of South Africa, South Africa.

- Dr. Daniel Binns, Academic Member, ATINER \& Lecturer, RMIT University, Australia.

- Dr. Binoy Kampmark, Lecturer in Social Sciences, School of Global, Urban and Social Studies, RMIT University, Australia.

- Dr. Sarah Sparke, Academic Member, ATINER \& Research Associate, CMIR, University of the West of England, UK.

- Dr. Vittoria Sacco, Postdoctoral Assistant, Neuchatel University, Switzerland.

- Ms. Mania Alehpour, PhD Candidate, University of Tehran, Iran.

- General Managing Editor of all ATINER's Publications: Ms. Afrodete Papanikou

- ICT Managing Editor of all ATINER's Publications: Mr. Kostas Spyropoulos

- Managing Editor of this Journal: Ms. Olga Gkounta (ㅁio $)$

\section{Reviewers' Board}

Click Here 


\section{President's Message}

All ATINER's publications including its e-journals are open access without any costs (submission, processing, publishing, open access paid by authors, open access paid by readers etc.) and is independent of presentations at any of the many small events (conferences, symposiums, forums, colloquiums, courses, roundtable discussions) organized by ATINER throughout the year and entail significant costs of participating. The intellectual property rights of the submitting papers remain with the author. Before you submit, please make sure your paper meets the basic academic standards, which includes proper English. Some articles will be selected from the numerous papers that have been presented at the various annual international academic conferences organized by the different divisions and units of the Athens Institute for Education and Research. The plethora of papers presented every year will enable the editorial board of each journal to select the best, and in so doing produce a top-quality academic journal. In addition to papers presented, ATINER will encourage the independent submission of papers to be evaluated for publication.

The current issue is the first of the seventh volume of the Athens Journal of Mass Media and Communications (AJMMC), published by the Mass Media \& Communication Unit of ATINER.

Gregory T. Papanikos

President

ATINER 


\section{Athens Institute for Education and Research}

\section{A World Association of Academics and Researchers}

19th Annual International Conference on Communication and Mass Media, 10-13 May 2021, Athens, Greece

The Mass Media \& Communication Unit of ATINER organizes its 19th Annual International Conference on Communication and Mass Media, 10-13 May 2021, Athens, Greece sponsored by the Athens Journal of Mass Media and Communications. The aim of the conference is to bring together academics and researchers of Communications, Mass Media and other related disciplines. Please submit a proposal using the form available (https://www.atiner.gr/2021/FORM-MED.doc).

- Abstract Submission: 11 January 2020

- Acceptance of Abstract: 4 Weeks after Submission

- Submission of Paper: 12 April 2021

\section{Academic Members Responsible for the Conference}

- Dr. John Pavlik, Head, Mass Media and Communication Research Unit, ATINER \& Professor, Rutgers University, USA.

- Dr. Yorgo Pasadeos, Director, Social Sciences Division, ATINER \& Professor Emeritus, University of Alabama USA.

\section{Social and Educational Program}

The Social Program Emphasizes the Educational Aspect of the Academic Meetings of Atiner.

- Greek Night Entertainment (This is the official dinner of the conference)

- Athens Sightseeing: Old and New-An Educational Urban Walk

- Social Dinner

- Mycenae Visit

- Exploration of the Aegean Islands

- Delphi Visit

- Ancient Corinth and Cape Sounion

\section{Conference Fees}

Conference fees vary from $400 €$ to $2000 €$ Details can be found at: https://www.atiner.gr/2019fees 


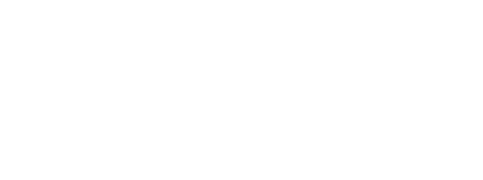




\title{
Framing Immigration and Illegal Immigration in the 2016 Presidential Campaigns: Comparing Donald Trump and Bernie Sander's Position'
}

\author{
By Jin Yang *
}

\begin{abstract}
This study compared the U.S. TV news coverage of Donald Trump's and Bernie Sanders' talking points on immigration in the 2016 presidential campaign. Utilizing six common frames on immigration in general and adopting framing's function approach (which consists of definition, causes and solutions aspects of an issue or a topic under discussion) to illegal immigration, the study content analyzed $153 \mathrm{TV}$ news transcripts. Trump's talking points highlighted the claim that immigrants were dangerous because they brought crimes to U.S., and they had to be deported and borders must be secured. Sanders' talking points emphasized the idea of a nation of immigrants where even illegal immigrants should be entitled to basic human rights, and immigration reform constituted a better solution. The causes for illegal immigration, however, were largely marginalized in the TV news coverage.
\end{abstract}

Keywords: Framing immigration, framing illegal immigration, framing's function approach, 2016 U.S. presidential campaign, U.S. TV news coverage of election

\section{Introduction}

Ethnic diversity and immigration may be the United States' most outstanding, if not the most unique, cultural and social threads of the fabric of the country. However, the public opinion reflected in the 1992-2002 ten-year Poll Trend indicates the public's ongoing negativity and ambivalence towards immigrants, and a strong anti-immigration sentiment after 9/11 (Muste, 2013). The year of 2016 witnessed more polarizing opinions among the U.S. electorate on immigration. As TV was a closely watched media platform by majority of voters, an analysis of how two 2016 presidential front-running candidates talked about immigration on TV would only be revealing.

The most common way for media elites, including politicians, to promote or define issues is through framing (Kim and Wanta, 2018). Research has shown that the framing of issues may have an effect on public perception and interpretation of issues (Chong and Druckman, 2007; Entman, 1993; Grabe and Bucy, 2008). Television, still the top source for election results in 2016 (Anderson, 2016), ranks as the second most popular political news platform after social media, even for millennials (Mitchell et al., 2016). Therefore, the U.S. television is one of the most important platforms to investigate. Second, Donald Trump and Bernie Sanders

\footnotetext{
*Professor, University of Memphis, USA.

${ }^{1}$ This research project was funded by the 2017 Faculty Research Grant of the University of Memphis.

The author would like to recognize and thank graduate student William Colter Prentis for his data coding assistance.
} 
represent typical positions on immigration among Republican and Democrat voters. Kathleen Parker, the columnist for the Washington Post, commented in a Sunday morning NBC news/interview program Meet the Press that "I actually see Trump and Sanders as sort of mirror images of each other in that they're representing the extremes of the base," (Meet the Press Transcript, 2015). Zooming in on their positions on immigration will efficiently uncover the complexity and subtlety of immigration. After all, immigration is not a monolithic issue, but a dividing issue not only along party lines but also among party members (Thompson, 2018). Third, though researchers have studied a diverse group of political issues, including immigration issues, in relation to presidential elections from the framing perspective, few have focused on the framing of immigration issue from the comparative approach.

Therefore, the study intends to adopt the theoretical framework of framing in analysing and comparing the TV news programs that have reported Trump and Sanders as presidential candidates talking about immigration. The six-commonimmigration frames developed by Quinsaat (2014) and the illegal immigration frames developed by Kim et al., (2011) based on Entman's (1993) conceptualization of functionality of framing are to be adopted in the study to provide a comprehensive picture of immigration in news by two front runners.

\section{Literature Review}

\section{Theoretical Framework of Framing}

In general, there are two kinds of frames based on where the frames are: in people's minds or in media texts. The first one, also known as audience frames (Cappella and Jamieson, 1997), or micro-constructs (Scheufele and Tewksbury, 2007) refers to the frames in the minds of individuals that help to process information and form their impression or perceptions of the world. The second one, known as media frames (Cappella and Jamieson, 1997), or macro constructs (Scheufele, 1999; Scheufele and Tewksbury, 2007) refers to modes of presentation that journalists and media communicators adopt in media discourses to deliver information (Shoemaker and Reese, 1996). While media frames are more relevant in this study, it is impossible not to mention audience frames in defining the frame construct.

The framing theory postulates that an issue can be examined from different perspectives for multiple values and views (Chong and Druckman, 2007). Framing, therefore, assists people in forming a particular idea of an issue or leading people's thinking about an issue (Chong and Druckman, 2007). Goffman (1974) defined "framing" as "schemata of interpretation" that allows users to organize experiences (p.46). Goffman's sociological approach to defining a frame becomes very useful for the study of journalistic messages because media has a great amplitude for producing social frameworks of interpretation and playing a key role in shared social discourse (Ardèvol-Abreu, 2015). While Goffman (1974) 
was usually credited as the first scholar to define the term framing, his definition seems to be more about the individuals' capacity to interpret the message.

Many other scholars and researchers defined framing from a media perspective. Entman (1993) noted that "to frame a communicating text or message is to promote certain facets of a "perceived reality" and make them more salient in such a way that endorses a specific problem definition, causal interpretation, moral evaluation, and/or a treatment recommendation" (p. 51). Tuchman (1978) pointed out that a news frame "organizes everyday reality" because news making is not only about reflecting and presenting the reality but also about constructing the reality (Tuchman 1978, p. 193). And that "central organizing idea" not only provides meaning to a series of events but also develops a connection among them (Gamson and Modigliani, 1989, p. 143). Shah et al., (2002), however, emphasized that a frame promotes "particular definitions and interpretations of political issues" (p. 343) which aligns well with Entman's (1993) take on framing: orienting readers.

The two approaches are not completely independent from each other. Thus, arises social constructionism that speculates such a relation: audience frames are closely related to media frames. Van Gorp (2007) points out that social constructionism is all about developing reality in social interaction. Media audiences are active in the sense of processing and interpreting what is made available to them (Wicks, 2001). However, mass media only delivers a limited range of persistent frames for audience to process (Pan and Kosicki, 1993; Reese, 2001). Eventually, these persistent frames help establish "interpretation of events" (Goffman, 1974) or thinking of a particular issue (Chong and Druckman, 2007) such as attributing responsibility treatments as concluded by Iyengar (1991) and Scheufele (2000). Thereupon, the functionality of frames in constructing social reality through definition, causal pinpoints and solutions by Entman (1993) is of particular importance in examining the frames of issues presented by the media.

\section{Media Framing of Presidential Campaigns}

Media frames matter a lot because they influence public attitudes and behaviors (Chong and Druckman, 2007). Grabe and Bucy (2008) noted that although political campaigns shape the candidate's public performances to a great extent, it is journalists who have the final say about what aspects of that performance are conveyed to audiences, and hence media retains some influence over the candidate's public image.

A majority of political science and communication literature is about how elites' frames (such as the ones of intellectuals, politicians and interest groups) influenced citizens' frames and attitudes (Chong and Druckman, 2007). While some researchers focused on the media bias or favors given to candidates, others compared how candidates were presented in different media platforms. For instance, D'Allessio and Allen (2000) conducted a meta-analysis of 59 studies that reviewed the media coverage of presidential elections. They concluded that no significant biases or favors were shown for candidates in the newspaper coverage, and the same was almost true of the TV coverage. Miller et al., (1998) studied and 
compared how 1996 GOP presidential candidates framed themselves in press releases and how elite newspapers covered them. They concluded that the four GOP candidates' images were distinct in press releases, but news stories distinguished the candidates even more and placed the candidates in very different positions. Grabe and Bucy (2008) identified very different partisan ways of presenting candidates. While Democrats tended to present their presidential candidates in a populist frame in network news, Republicans preferred to present theirs in an ideal candidate frame with linkages to patriotic symbols. Lowry and Xie (2007) studied the 2004 presidential campaign coverage by TV news in comparison to the coverage in the years of 1996 and 1992. They concluded that cable news, CNN and Fox News, were more interested in covering poll stories and security issues while the networks displayed more interested in traditional topics of economy and religion. Kim and Wanta (2018) studied the frames used in the four major U.S. newspaper coverage of the immigration debate during election years. They found that conflict frame was the most dominant frame, followed by human interest frame as the second frame and horse-race frame as the third frame. They also found that "illegal" was the most frequently associated characteristic attached to the immigrants.

If issues and policies are the most important attention points in a presidential election, what seems to be needed is the comparison of candidates' positions, especially on pressing issues. How one candidate distinguishes himself/herself from the rest in terms of their stances on issues is not only what holds him/her accountable in the future terms if elected, but also acts as a campaign strategy that may resonate with and appeal to voters. This study attempts to focus on the issue of immigration by comparing the views of the Republican candidate and the Democrat candidate on immigration in general, and illegal immigration in particular. The study wants to gauge how two candidates' positions on immigration were framed on TV. And most important of all, the study is especially interested in finding out how the illegal immigration issue was talked about by the two candidates.

\section{Immigration in the United States}

Ashley (2006) points out that America is a "nation of immigrants" but not "a nation of illegal immigrants" emphasizing that "immigration is not the same thing as illegal immigration," (p. 344). Unfortunately, these two terms get intertwined and mixed up in political talks and mass communication discourses. Politicians and media tend to associate the general term of immigration with the specific term of illegal immigration, causing legal immigration somehow to fade into the background. However, the 2018 Current Population Survey reveals that $28 \%$ of the overall U.S. population (89.4 million) were legal immigrants (Zong et al., 2019) while $3.2 \%$ of the nation's population (10.5 million) were illegal immigrants in 2017 based on Pew Research Center's results (Radford, 2019). Moreover, the portrayals of immigrants are mostly negative (Farris and Mohamed, 2018).

Foreign-born population inflated from 9.6 million (4.7 \% of U.S. population) in 1970 to 28.4 million (10.4\% of the U.S. population) in 2000 (Camarota, 2001) 
due to the 1965 landmark law $^{2}$ that rewrote U.S. immigration policy (Pew Research Center, 2015). However, after September 11, 2001, the trend completely changed. President George W. Bush launched border security initiatives in 2003, including measures on terrorist attack, illegal immigration and drug smuggling (Securing the Homeland and Strengthening the Nation, n.d.). The U.S. government developed the Department of Homeland Security (Chishti and Bergeron, 2011), and legislators focused on tackling immigration from the perspective of homeland security (Quinsaat, 2014).

Even the academic world began to hear a different voice about immigrants. Political scientist and historian Huntington (2004) suggested that the biggest problem of Latin American immigration, and especially Mexican immigration, to the U.S. is the so-called "Hispanization," which may lead the country toward a demographic "Reconquista" of the U.S. regions (p. 221).

On the public front, some activist organizations, such as The Minuteman Project whose mission is to monitor the flow of undocumented immigrants by setting up watch posts and even armed forces along the Arizona-Mexico border, have attracted far more media attention and public debate on illegal immigration (Chavez, 2008).

All these forces led to several national and state-level legislative measures. In 2005, the U.S. house of representatives introduced a bill named Border Protection, Anti-Terrorism, and Illegal Immigration Control Act (H.R. 4437) and passed it by a vote of 239 to 182, though the bill failed in the Senate (Archibold, 2010). In 2009, the state of Arizona passed a bill on law enforcement support and neighborhood safety, which was probably the harshest anti-illegal immigration act in history (Archibold, 2010).

The most recent significant development in immigration concerns the termination of Deferred Action for Childhood Arrivals or DACA ${ }^{3}$ by the Trump administration (Schallhorn, 2018). The DACA program, developed in the Obama era, allowed minors who arrived at the U.S. illegally to be free from deportation. Trump's termination was invalidated by a federal judge in California, thus the Trump administration has to resume accepting DACA renewals (Chavez, 2018). USCIS has resumed accepting requests to renew a grant of deferred action under DACA, however, the future of DACA remains to be decided.

The public opinion on DACA reveals a striking 42-point partisan difference. While only $50 \%$ of the Republicans say it is all right to grant permanent legal status to immigrants who entered the U.S. illegally when they were children, it is an overwhelming majority of $92 \%$ of the Democrats who say so (Tyson, 2018).

\footnotetext{
${ }^{2}$ The 1965 Immigration and Nationality Act wiped out the national origins quota system that had favored immigrants from Europe and replaced it with one that values family reunification and skilled immigrants (Pew Research Center, 2015). As a result, more than half (51\%) of the new immigrants are from Latin America and one-quarter from Asia (Pew Research Center, 2015).

${ }^{3}$ Deferred Action for Childhood Arrivals (DACA) is a kind of administrative relief from deportation. The purpose of DACA is to protect eligible immigrant youth who came to the United States when they were children from deportation. DACA gives young undocumented immigrants: 1) protection from deportation, and 2) a work permit. The program expires after two years, subject to renewal. Excerpt from https://undocu.berkeley.edu/legal-support-overview/what-is-daca/.
} 
Immigration may be the No. 1 issue in the 2016 presidential campaign due to its conflicting nature and complication (Jones, 2015). Therefore, in a close primary or general election contest, even if immigration is less important than economy and other issues, the election outcome could be totally dictated by the immigration stand (Jones, 2015).

Therefore, the study intends to investigate how immigration in general was framed by presidential candidates via the U.S. television, and then it zooms in on how illegal immigration was framed by presidential candidates in the U.S. television. Here are two research questions to be addressed in this study.

Q1. How was the immigration issue framed by the 2016 presidential candidates Donald Trump and Bernie Sanders in the U.S. television?

Q2. How was the illegal immigration issue framed by the 2016 presidential candidates Trump and Bernie Sanders in the U.S. television?

\section{Method}

\section{Sampling}

The sample of the six U.S. TV news transcripts (i.e., CNN, MSNBC, Fox News, ABC, CBS, NBC) was obtained from the Lexis-Nexis database. The time frame for the sample starts from the two candidates' formal announcement dates to enter the race. Trump's time frame starts from June 16, 2015 and Sanders' from May 26, 2015. The end date of the time frame for both candidates is June 16, 2016, when Sanders announced that he would exit the race and work with Clinton to defeat Trump in the presidential election. In collecting samples for both candidates, the author found that there were more news transcripts on Trump than on Sanders. Therefore, to create comparable samples for both candidates, June 16 was also set as the end date for the Trump sample. The study used all the news transcripts available for the Sanders' sample because the TV news coverage on Sanders' position turned out to be much fewer than expected. For Trump's sample, a constructed month sampling technique was taken. The Trump sample ended up with 101 news transcripts, and the Sanders sample with 52 news transcripts.

\section{Measurements}

To examine immigration in general, the study borrowed Quinsaat's (2014) approach to frames that were derived from his inductive analysis of news story data and theoretical constructs speculated from literature review. Quinsaat's (2014) findings yielded six common frames on immigration: Nation of Immigrants, Failed Immigration Policy, Dangerous Immigrants, Cheap Labor, Immigrant Takeover, Immigrant-as-Other. These six frames, developed in the examination of immigration coverage on news media, can serve as generic frames for the immigration issue. The frame of "Nation of Immigrants" (NOI) features the immigrant history of the United States, honors the process of becoming a citizen, 
supports undocumented immigrants' protests, promotes their human rights and promises not deporting them (Quinsaat, 2014, p. 583). The frame of "Failed Immigration Policy" (FIP) criticizes the failure of the country to address the immigration problem, or the inability of the government to perform its role resolving the conflicts between local and the federal governments, and wordings such as border control, rules of laws and similar words often appear in such a frame (Quinsaat, 2014, p. 584). The frame of "Dangerous Immigrants" (DI) concerns national security, and wordings such as terrorists, terrorism, professional agitators, criminals, bad people are associated with immigrants (Quinsaat, 2014, p. 585). The frame of "Cheap Labor" (CL) stresses the economic factors that drive immigration, as this frame is more about poverty, jobs, and unequal incomes and resources (Quinsaat, 2014, p. 586-587). The frame of "Immigrant Takeover" (IT) applies a demographic perspective on the issue, voicing the concern that the minority of population becomes the majority, and the U.S. population composition shifts and changes (Quinsaat, 2014, p. 588-589). The frame of "Immigrant-asOther" (IAO) offers a pessimistic view on the assimilation of immigrants in that immigrants' faith, values, beliefs, and cultural inheritance are difficult to integrate in the mainstream U.S. system (Quinsaat, 2014, p. 590-591). The study measured the six common frames at the ratio level by counting the frequency, or the number of times, a particular common frame appeared in the TV news transcripts.

The study examined the illegal immigration issue coverage using Entman's (1993) idea about the key functions of framing from a social constructionism approach. Basically, illegal immigration is investigated from three aspects: how it is defined, how its causes, or root, are explained and what solutions are offered. Kim et al., (2011) adopted such an approach in examining six regional and national newspapers' coverage of illegal immigration. Their definitions of illegal immigration reside in whether illegal immigrants were reported in the context of crimes, social costs, national security, safety, job loss, basic human rights requirement, and others, all of which were measured at the nominal level with dichotomous categories of yes and no in this study. Likely causes for illegal immigrants were operationalized by Kim et al., (2011) as Latin America's economic problems, U.S. immigration system's failure, U.S. weak border control, lack of strong law enforcement, and others, all of which were measured as the binary code of yes or no in this study. Lastly, solutions for the illegal immigration problem were defined by Kim et al., (2011) as consisting in six categories: helping Latin America economy, immigration reform, tougher border control, stricter law enforcement, deportation of immigrants and others. Again, the measurement was taken as the binary code of yes or no for each category in this study.

One graduate student and the researcher worked on the sample coding. Three rounds of trainings were taken until the inter-coder reliabilities, i.e., Scott's pi (p), for all variables reached at least 0.80 . 


\section{Results}

The study analysed a total of 153 TV news transcripts with $66 \%$ on Trump and $34 \%$ on Sanders. Six TV networks or cable services were included: CNN (36\%), Fox News (23\%), MSNBC (13\%), ABC (9\%), NBC (6\%) and CBS (13\%). With regards to news transcript types, $61 \%$ are talk show programs, followed by video clips $(34 \%)$, the rest $5 \%$ are interviews, combined news packages and others. The entire TV news transcripts totalled 741,096 words ranging from 366 words per story to 15,822 words per story, with an average of 4,844 words per story. For the Trump sample, the story's average length is 5,051 words, and for Sanders', it is 4,440 words. The sampling frame covers 354 days, almost one year. There are two coverage peaks: August 17-18, 2015, when Trump released his plan to combat illegal immigration, and March 10, 2016, when Sanders and Clinton debated for the eighth time the previous day and Republican candidates debated for the last time.

Q1. How was the immigration issue framed by the 2016 presidential candidates Donald Trump and Bernie Sanders in the U.S. television?

Six common frames were examined in every transcript at the ratio level. That means every frame was measured as an independent variable. Then independent sample t-test was run for the comparison between Trump and Sanders. The SPSS output revealed that Nation of Immigrants frame was significantly $(\mathrm{t}=6.89$, $\mathrm{df}=151, \mathrm{p}<0.001)$ more associated with Sanders $(\mathrm{M}=1.40, \mathrm{SD}=1.33)$ than with Trump $(\mathrm{M}=.11, \mathrm{SD}=.34)$. And Trump was much more associated with the frame of Dangerous Immigrants $(M=1.07, S D=1.38)$ than Sanders $(M=0 ; S D=0$;). The analysis was significant $(\mathrm{t}=5.58, \mathrm{df}=151, \mathrm{p}<0.001)$. The frame of Failed Immigration Policy was more associated with Trump $(\mathrm{M}=1.86, \mathrm{SD}=1.70)$ than with Sanders $(\mathrm{M}=0.92, \mathrm{SD}=1.56)$. The $\mathrm{t}$-test was significant $(\mathrm{t}=3.33, \mathrm{df}=151$, $\mathrm{p}>0.01$ ).

Only 16 stories, or $10 \%$ of the 153 stories, carried the other three common frames of Cheap Labor, Immigration Takeover and Immigrant-as-Other in the U.S. TV news. Therefore, no statistical analysis can be run for these three common frames in the sample.

Q2. How was the illegal immigration issue framed by the 2016 presidential candidates Donald Trump and Bernie Sanders in the U.S. television?

Illegal immigration was analysed from three different aspects: its definition, its causes and its solutions. In comparing the candidates' definitions of illegal immigration, the Chi-square test was run to identify the differences between the two candidates in seven categories of crimes, social costs, national security, safety, job loss, basic human rights requirement, and others. The overall finding produced by the Chi-square was significant $\left(\chi^{2}=33.06, p<0.001\right)$. Therefore, $z$-test was run on the individual definition to check whether the specific definition differed significantly. It was found that the candidates differed in defining illegal 
immigration as crime (z-test $\mathrm{p}<0.05$ ), in defining illegal immigration as a concern for their safety (z-test $\mathrm{p}<0.05$ ), and in defining illegal immigration as a basic human rights issue (z-test $\mathrm{p}<0.05)$. In other words, Trump was more likely to define illegal immigration as crime (13.1\% vs. 0), but Sanders was more likely to define it as a safety concern (0 vs. $5.9 \%)$ and as a basic human rights concern ( $0.7 \%$ vs. $2.6 \%)$. See Table 1 for details.

Table 1. Relationships between Candidates and Illegal Immigration Definition

\begin{tabular}{|l|c|c|c|}
\hline \multirow{2}{*}{$\begin{array}{l}\text { Deflegal Imminition (how candidates } \\
\text { present it as a problem) }\end{array}$} & Trump & Sanders & z-test \\
\cline { 2 - 4 } & $51.6 \%$ & $25.5 \%$ & $\mathbf{p}<\mathbf{0 . 0 5}$ \\
\hline No Mention & $13.1 \%$ & 0 & \\
\hline Crime & 0 & 0 & $\mathbf{p}<\mathbf{0 . 0 5}$ \\
\hline Nocial Cost & 0 & 0 & $\mathbf{p}<\mathbf{0 . 0 5}$ \\
\hline $\begin{array}{l}\text { Safety of Illegal } \\
\text { Immigrants }\end{array}$ & 0 & $5.9 \%$ & \\
\hline Jobs Taking Away & $0.7 \%$ & 0 & \\
\hline Basic Human Rights & $0.7 \%$ & $2.6 \%$ & \\
\hline Total & $66 \%$ & $34 \%$ & \\
\hline$\chi 2=33.06, d f=4, p<0.001$ & & &
\end{tabular}

In terms of causes for illegal immigration, $96.7 \%$ of the stories did not mention any causes. Among the rare $3.3 \%$ of the stories that did talk about causes, only one cause of weaker control was mentioned. Therefore, there was not enough data to run the analysis.

Table 2. Relationships between Candidates and Illegal Immigration Solutions

\begin{tabular}{|l|c|c|c|}
\hline \multirow{2}{*}{\begin{tabular}{l} 
Sllegal Immigration \\
\cline { 2 - 4 }
\end{tabular}} & Trump & Sanders & z-test \\
\hline No mention & $62.4 \%$ & $51.9 \%$ & \\
\hline $\begin{array}{l}\text { Helping Latin } \\
\text { American Economy }\end{array}$ & 0 & 0 & $\mathbf{p}<\mathbf{0 . 0 5}$ \\
\hline Immigration Reform & $\mathbf{0 . 7 \%}$ & $\mathbf{1 6 . 3 \%}$ & $\mathbf{p}<\mathbf{0 . 0 5}$ \\
\hline $\begin{array}{l}\text { Tougher Border } \\
\text { Control }\end{array}$ & $\mathbf{4 . 6 \%}$ & $\mathbf{0}$ & \\
\hline $\begin{array}{l}\text { Stricter Law } \\
\text { Enforcement }\end{array}$ & 0 & 0 & $\mathbf{p}<\mathbf{0 . 0 5}$ \\
\hline Deportation & $\mathbf{1 9 . 6 \%}$ & $\mathbf{0}$ & \\
\hline Others & $66 \%$ & $34 \%$ & \\
\hline Total & \multicolumn{4}{l}{} \\
\hline$\chi 2=64.47, \mathrm{df}=3, \mathrm{p}<0.001$ &
\end{tabular}

In analysing candidates' frames of solutions of illegal immigration, the Chisquare test produced a significant finding $\left(\chi^{2}=64.47, \mathrm{df}=3, \mathrm{p}<0.001\right)$ which suggests there was a big difference between the two candidates in six categories: helping Latin America economy, immigration reform, tougher border control, stricter law enforcement, deportation of immigrants and others. The following ztests were run to identify the specific solution differences. The study found that 
Trump and Sanders differed in the following solutions: immigration reform (z-test $\mathrm{p}<0.05$ ), border control (z-test $\mathrm{p}<0.05$ ) and deportation (z-test $\mathrm{p}<0.05)$. In other words, Sanders $(16.3 \%)$ was more likely than Trump $(0.7 \%)$ to support the immigration reform as a solution. Trump (4.6\%) was more likely to support the solution of tougher border control than Sanders (0), and support the solution of deportation (19.6\%) than Sanders (0). See Table 2 for details.

\section{Discussion and Conclusion}

The two front-running candidates for the Republican and Democrat parties, Trump and Sanders, diverged from each other on the immigration issue in the 2016 primary election. Trump's primary talking points were that U.S. has a failed immigration policy and immigrants are dangerous because they bring crimes to this country, and they have to be deported and borders have to be secured. And Sanders' talking points were that this is a nation of immigrants, even illegal immigrants should enjoy basic human rights and deserve humane treatment, and the immigration reform is a much better solution.

What should be noted is the general immigration issue, framed as the issues of dangerous immigrants and failed immigration policy by Trump, indicates his tendency to intermingle the general immigration issue with the illegal immigration. His defining illegal immigration as a crime reinforces the already negative portrayals of immigrants in this country, and his solutions of deportation can only intensify the general perception of negativity towards immigrants.

Interestingly, the study identified two opposite outstanding solutions for illegal immigration: tougher border control and deportation by Trump, and immigration reform by Sanders, which are in line with the findings by Kim et al., (2011). The two very different solutions to reducing illegal immigration reflects the partisan differences in tackling illegal immigration and are very reflective of the American public's fundamental differences in visioning illegal immigration.

Surprisingly, the discussion of the causes of illegal immigration was marginalized in this general election coverage. The causes of illegal immigration deserve more news space for speculating, elaborating and discussing because a comprehensive knowledge of the problem of illegal immigration must start with causes. The marginalization of causes may miss the most critical piece of the complicated picture.

TV news plays a significant role in informing the public about issues, especially in the time of presidential elections. The candidates' positions on immigration are made quite salient via the framing devices. Social constructionism notes that framing contributes to the creation and institutionalization of reality in social interaction, where an active audience interprets and evaluates media texts based on the available persistent frames. Therefore, in constructing the immigration reality, audiences would either have quite a negative picture of immigrants, and thus support the deportation, or have a sympathetic perception of immigrants and support the initiative of reform. This either-or institutionalization of immigration may only reinforce the already polarizing views of immigration and exclude the 
middle-ground views or the possible third view or fourth view of immigration. As such, a complicated issue, such as immigration, is reduced to a simple battling issue between parties.

Theoretically and empirically, framing is very useful in exploring and investigating a controversial issue from a comparative perspective: either across media platforms or across points of views. Generic frames identified from prior studies may be adopted repeatedly to synthesize conclusions on issues. Entman's functionality of frame taking up definitions, causes and solutions of issues provides a multi-angle view of what is under discussion. Functioning as a telescope lens and as a microscope lens on issues, this framing device may be universally applicable to any complicated social, political, economic and scientific issues.

This study makes some contribution to the theoretical development of framing in that generic media frames such as issue definitions, causes, and solutions enabling a consistent analysis of media content, and allowing the possibility of building a structured model on framing in future. Another contribution lies in the fact that social constructionism connects media frames and audience frames perfectly. Instead of treating the two types of frames as two independent entities, an empirical study from the social constructionism perspective may mobilize and integrate both frames in research endeavours to cover media frames on one end and audience frames on the other. After all, social constructionism is about how audiences interpret and understand issues in social interactions based on how issues are framed in mass media.

\section{Limitations and Suggestions}

While framing is useful, we have to admit the classification of immigration into categories, such as Nation of Immigrants or Dangerous Immigrants, resorts to the stereotypical depiction of immigrants by simplifying their human conditions and circumstances. The full stories of immigrants, especially illegal immigrants, seem impossible to tell with this framing analysis. Through framing, the social construction of an immigrant as a citizen (in Nation of Immigrants), a criminal (Dangerous Immigrant), a dispensable worker (in Cheap Labor), an invader (in Immigrant Takeover) or a forever foreigner (in Immigrant-as-Other) (Quinsaat, 2014) is constrained by the singular value judgement of good versus bad, and trapped in the traditional monolithic reasoning of right versus wrong. Moreover, defining illegal immigration as crime is even more value-laden. While Democrat candidate Sanders did define illegal immigration as a safety and human rights issue, his voice may have gotten lost in the more dominant coverage of Trump.

This study only analysed 153 news transcripts, with $66 \%$ dedicated to Trump and $34 \%$ to Sanders, and the sample size could have been much larger by including regional TV stations with a large TV audience market. The manual coding of the variables could not fully address the reliability and validity problems, and the use of a computer-assisted textual analysis may confirm and complement the findings. 
Future analysis may consider the integration of surveying public perception of immigration so that a direct relationship between media coverage and public perception can be identified and inquired. After all, the effect of media message on the public would be more meaningful because that is what counts most. Lastly, a comparative study between TV news coverage and print news coverage would be more interesting, as print news generally provides in-depth analysis of current events in which the causation aspect of illegal immigration may not be marginalized and excluded.

\section{References}

Anderson, M. (2016). TV still the top source for election results, but digital platforms rise. Retrieved from: http://www.pewresearch.org/fact-tank/ 2016/11/21/tv-still-the-topsource-for-election-results-but-digital-platforms-rise/. [Accessed 22 November 2016].

Archibold, R. C. (2010). U.S.'s toughest immigration law is signed in Arizona. The New York Times.

Ardèvol-Abreu, A. (2015). Framing theory in communication research in Spain. Origins, development and current situation. Revista Latina de Comunicación Social, 70(Jan), 423-450.

Ashley, L. R. N. (2006). Bordering on the impossible. ETC: A Review of General Semantics, 63(3), 343-348.

Camarota, S. A. (2001). Immigrants in the United States - 2000. Retrieved from: https://cis.org/Report/Immigrants-United-States-2000. [Accessed 9 March 2020].

Cappella, J. N., Jamieson, K. H. (1997). Spiral of cynicism: the press and the public good. New York: Oxford University Press.

Chavez, L. R. (2008). The Latino threat: constructing immigrants, citizens, and the nation. Stanford, CA: Stanford University Press.

Chavez, N. (2018). Trump administration resumes accepting DACA renewals. Retrieved from: http://www.cnn.com/2018/01/13/ politics/daca-resumes-renewals/index.html. [Accessed 21 January 2018].

Chishti, M., Bergeron, C. (2011). Post-9/11 policies dramatically alter the U.S. immigration landscape. Retrieved from: https://bit.ly/3eOL81K. [Accessed 24 January 2018].

Chong, D., Druckman, J. (2007). Framing public opinion in competitive democracies. The American Political Science Review, 101(4), 637-655.

D'Alessio, D., Allen, M. (2000). Media bias in presidential elections: a meta-analysis. Journal of Communication, 50(4), 133-156.

Entman, R. M. (1993). Framing: toward clarification of a fractured paradigm. Journal of Communication, 43(4), 51-58.

Farris, E. M., Mohamed, H. S. (2018). Picturing immigration: how the media criminalizes immigrants. Politics, Groups, and Identities, 6(4), 814-824.

Gamson, W. A., Modigliani, A. (1989). Media discourse and public opinion on nuclear power: a constructionist approach. American Journal of Sociology, 95(1), 1-37.

Grabe, M., Bucy, E. (2008). The struggle for control: visual framing, news coverage, and image handling of presidential candidates, 1992-2004. Conference Papers International Communication Association, 1-42.

Goffman, E. (1974). Frame analysis: an essay on the organization of the experience. New York: Harper Colophon. 
Huntington, S. P. (2004). Who are we? The challenges to America's national identity. New York: Simon \& Schuster.

Iyengar, S. (1991). Is anyone responsible: how television frames political issues. Chicago: University of Chicago Press.

Jones, J. M. (2015). One in five voters say immigration stance critical to vote. Retrieved from: https://bit.ly/30viIF9. [Accessed 24 January 2018].

Kim, S., Carvalho, J. P., Davis, A. G., Mullins, A. M. (2011). The view of the border: news framing of the definition, causes, and solutions to illegal immigration. Mass Communication \& Society, 14(3), 292-314.

Kim, J., Wanta, W. (2018). News framing of the U.S. immigration debate during election years: focus on generic frames. The Communication Review, 21(2), 89-115.

Lowry, D., Xie, L. (2007). Agenda-setting and framing by topic proximity: a new technique for the computerized content analysis of network TV news presidential campaign coverage. Conference Papers - International Communication Association, 1.

Meet the Press Transcript - July 5, 2015 (2015). Retrieved from: http://www.nbcnews. com/meet-the-press/meet-press-transcript-july-5-2015-n386996. [Accessed 27 September 2016].

Miller, M. M., Andsager, J. L., Riechert, B. P. (1998). Framing the candidates in presidential primaries: issues and images in press releases and news coverage. Journalism \& Mass Communication Quarterly, 75(2), 312-324.

Mitchell, A., Gottfried, J. Matsa, K. E. (2016). Millennials and political news: social media - the local TV for the next generation? Retrieved from http://www.journalism. org/2015/06/01/millennials-political-news/. [Accessed 22 November 2016].

Muste, C. P. (2013). The dynamics of immigration opinion in the United States, 19922012. Public Opinion Quarterly, 77(1), 398-416.

Pan, Z. P., Kosicki, G. M. (1993). Framing analysis: an approach to news discourse. Political Communication, 10(1), 55-75.

Pew Research Center (2015). Modern immigration wave brings 59 million to U.S., driving population growth and change through 2065. Retrieved from: https://pewrsr.ch/39 dXGi6. [Accessed 5 June 2020].

Quinsaat, S. (2014). Competing news frames and hegemonic discourses in the construction of contemporary immigration and immigrants in the United States. Mass Communication \& Society, 17(4), 573-596.

Radford, J. (2019). Key findings about U.S. immigrants. Retrieved from: https://www.pew research.org/fact-tank/2019/06/17/key-findings-about-u-s-immigrants/. [Accessed 15 October 2019].

Reese, S. D. (2001). Introduction. In S. D. Reese, O. H. Gandy, A. E. Grant (Eds.), Framing public life: Perspectives on media and our understanding of the social world (pp. 1-31). Mahwah, NJ: Erlbaum.

Schallhorn, K. (2018). What is DACA and why is the Trump administration ending it? Retrieved from: http://www.foxnews. com/politics/2018/01/15/what-is-daca-andwhy-is-trump-administration-ending-it.html. [Accessed 21 January 2018].

Scheufele, D. A. (1999). Framing as a theory of media effects. Journal of Communication, 49(1), 103-122.

Scheufele, D. A. (2000). Agenda-setting, priming, and framing revisited: another look at cognitive effects of political communication. Mass Communication \& Society, 3(23), 297-316.

Scheufele, D. A., Tewksbury, D. (2007). Framing, agenda setting, and priming: the evolution of three media effects models. Journal of Communication, 57(1), 9-20. 
Securing the Homeland and Strengthening the Nation (n.d.). Retrieved from https://www.dhs.gov/publication/securing-homeland-strengthening-nation. [Accessed 30 November 2016].

Shah, D. V., Watts, M. D., Domke, D., Fan, D. P. (2002). News framing and cueing of issue regimes: explaining Clinton's public approval in spite of scandal. Public Opinion Quarterly, 66(3): 39-70.

Shoemaker, P. J., Reese, S. D. (1996). Mediating the message: theories of influences on mass media content. $2^{\text {nd }}$ Edition. White Plains, NY: Longman.

Thompson, D. (2018). How immigration became so controversial. Retrieved from: https://bit.ly/30zj9hp. [Accessed 20 August 2019].

Tuchman G. (1978). Making news. New York: The Free Press.

Tyson, A. (2018). Public backs legal status for immigrants brought to U.S. illegally as children, but not a bigger border wall. Retrieved from https://pewrsr.ch/3jskPlx. [Accessed 26 January 2018].

Van Gorp, B. (2007). The constructionist approach to framing: bringing culture back in. Journal of Communication, 57(1), 60-78.

Wicks, R. H. (2001). Understanding audiences: learning to use the media constructively. Mahwah, NJ: Erlbaum.

Zong, J., Batalova, J., Burrows, M. (2019). Frequently requested statistics on immigrants and immigration in the United States. Retrieved from: https://bit.ly/3js3mtq. [Accessed 15 October 2019]. 


\title{
Value-Based Communication during Covid-19 Pandemic: A Study on the Twitter Messages of Turkish Ministry of Health
}

\begin{abstract}
By Seda Mengu* ${ }^{*}$ Murat Mengu ${ }^{ \pm} \&$ Kemal Gunay*
Influencing the whole world by obliging people to change their daily practices along with their relations and assume different life styles, Covid-19 has brought about some likely deleterious effects in Turkey as well. Undoubtedly, it has caused disturbance and even panic in social and psychological sense. In such cases of uncertainty and panic, communication with the public should be clear, explicit, alleviating and to some extent, guiding. People can be guided and convinced more easily if the level of distress and uncertainty decreases. Such a way of governing and compelling communication consists of different directions, requirements and combined effort. If co-operation is appropriately based on values, this process will be much easier. To that end, public discourse during the outbreak of the pandemic in 2019 was as successful as it was based on the daily life and language of society. Noteworthy, there are similarities between value-based collaboration and governmentality. Policies, customs, patterns and guidelines help maintain control and guidance over collaboration. At this point cooperation acts as a matter of participating in language games that build social and organisational realities that are created, debated, distributed and changed by means of mutual action and cooperation. The purpose of this study is to analyse the messages sent by the Ministry of Health during the pandemic in Turkey via social media, particularly Twitter, in order to find out to which extent these messages encompass the features of value-based communication. Thus, discourse analysis and descriptive research model are going to be implemented together. More specifically, the first tweet in which Corona was first referred was sent on January 25, 2020 and from then on 505 Tweets were posted. For the discourse analysis, 100 tweets that have received the most interaction are going to be used. As for the other descriptive analyses; on the other hand, all 505 tweets are going to be utilized in cluster analysis.
\end{abstract}

Keywords: value-based communication, discourse, social media, pandemic

\section{Introduction}

Covid-19 pandemic, which has produced dramatic consequences all over the world including Turkey, has also brought about some psychological and behavioural problems along with biological ones. What has spread is not only the virus but also some psychological disorders triggered by social trauma, such as excessive phobic reactions, depression, panic and paranoia as well as disruptive behavioural disorders, for instance selfishness, impulsivity selfishness, aggression

\footnotetext{
"Professor, Head, Public Relations and Publicity Department, Faculty of Communication, Istanbul University, Turkey.

${ }^{ \pm}$Associate Professor, Head, New Media and Communication Department, Faculty of Communication, Istanbul Arel University, Turkey.

${ }^{*} \mathrm{PhD}$ Researcher, Public Relations and Publicity Department, Faculty of Communication, Istanbul University, Turkey.
} 
and stigmatisation. In extraordinary situations people may temporarily lose their ethical values such as common sense, empathy, co-operation etc. and turn to an egotist creature. That is why, the psychological atmosphere created by pandemics spread faster than the virus itself and affect even those who have a low risk of catching it. Hence, a pandemic brings along an intrinsic psychological state. It can be considered as an aggression proved by the fear of death. Individuals who have become apprehensive and selfish tend to get rid of the ones who pose a threat and guarantee their well-being. Another problem that is observed in epidemics and pandemics is stigmatisation. Major cholera and plague epidemics throughout history have been collective traumas for humankind. Therefore, people have always been scared of such epidemics and thus, tended to ostracise and even eradicate the patients. Although the attitude today is not so cruel, it can be suggested that the respective Covid-19 has caused some sort of stigmatisation.

Covid-19 has also caused some harmful effects in Turkey by bringing about disturbance and even panic in social and psychological sense. In such cases of uncertainty and panic, communication with the public should be clear, explicit, alleviating and to some extent, guiding. People can be guided and persuaded more easily with regard to the increase or reduction of anxiety and ambiguity. Such a leading and persuasive communication consists of various rules, regulations and collaborations. In value-based collaboration, this process will be managed more easily. Thus, discourses towards the public during the outbreak of pandemic have been performed to maintain value-based collaboration. This approach has proved to be successful as it has been based on daily life and the language of society. According to Foucault (qtd. in Jørgensen, 2004) value-based collaboration as a new form of governance resembles governmentality. Collaboration is controlled and guided by a set of rules such as procedures, traditions, norms and standards. Moreover, collaboration functions as a matter of participating in language games through which social and organizational realities are structured (Adolpsen and Norreklit, qtd. in Jørgensen, 2004: 87). In other words, organizational and social realities are formed, negotiated, shared and changed through interaction and collaboration. In fact, collaboration enables people not only to communicate, but also maintain mutual understanding and perform daily life practices (Silverman and Jones qtd in Jørgensen, 2004). Value-based communication generally consists of being people oriented, quality, participation, sustainable communication, trust, transparency, conformity with ethical standards, continual research, susceptibility to needs, qualitative and quantitative as well as continuing education etc.

One of the two significant concepts in this study is value-based collaboration. Thus, with regard to the pandemic, whether or not value-based collaboration has been achieved and people have been led effectively with the language used is examined. In accordance with value-based collaboration, the second important concept is value-based communication. Within the context of this study, the main criteria and sub-categories of value-based communication have been determined as follows: 


\section{Main Criterion: Governance}
a) Participation of stakeholders into the process/katılımc1lik.
b) Clarity.
c) Transparency.
d) Accountability.

II. Main Criterion: Trust
a. Providing continuous information/feedback.
b. Giving Priority to Quality/Quality in Healthcare.
c. Reciprocity.
d. Dialogue.
e. Interaction.
f. Assuming Responsibility.
g. Conformity with Ethical Standards.

III. Main Criterion: Actions Pertaining to People Oriented Health Care:
a. Meeting the Needs.
b. Qualified Health Care Personnel.
c. Quick Response.
d. Early Diagnosis.
e. Research (developing vaccination etc.)
f. Providing education to patients, doctors and whole society about the pandemic.
g. Value Based on Distribution: Equal Distribution of Resources to All Patient Groups.
h. Technical Value: Optimum Output with Available Sources.
i. Personal Value: Proper Care for the Fulfillment of Patients' Expectations.
j. Social Value: Contribution of Health Services to Social Participation and Connectedness (European Union, 2019).

All in all, the purpose of this study is to analyse the messages sent by the Ministry of Health during the pandemic in Turkey via social media, particularly Twitter, in order to find out to which extent these messages encompass the features of value-based communication. Thus, discourse analysis and descriptive research model have been implemented together. More specifically, the first tweet in which Corona was first referred was sent on January 25, 2020 and from then on 505 Tweets were posted. For the discourse analysis, 100 tweets that have received the most interaction are going to be used. As for the other descriptive analyses; on the other hand, all 505 tweets are going to be utilized in cluster analysis. 


\section{Literature Review}

\section{Value-Based Communication during the Pandemic Process}

In this study, a review was carried out on whether the nature of messages sent by the Turkish Minister of Health to communities through Twitter was in accordance with value-based communication. First of all, the main and sub-criteria of value-based communication have been determined and the concepts and discourses that set these criteria have been analyzed. Social media's new community creation and community management issues are important here. Social media is one of the tools used to gather people together around specific issues and get them moving in a certain direction. Social media has become one of the new social capital building tools.

As Szecsi and Koller (2017: 18) stated, the essence of social capital of community is the trust among individuals which enables a community to accomplish more with individuals' physical and mental capacities than they can achieve alone. In other words, social capital of community can be considered as an ability of individuals to cooperate for common communal objectives, which is influenced by social interaction and communication, relations of trust, communal norms and values. In this way, social networks of the individuals are formed.

Social media, as a social network area, also provides a share of various norms and values. Messages sent through Twitter during the pandemic process are created to increase the ability of individuals to collaborate for common goals in society. Discarded messages are aimed at demonstrating the importance of pandemic, what needs to be done, the risks, the measures that need to be taken, and motivating their cooperation on communities.

It is claimed that the best communities are indeed the hybrids of physical and virtual communities (Etzioni, 2001, Haythornthwaite and Kendall, 2010 qtd. in Szecsi and Koller, 2017: 20). In these new, hybrid forms of communities, virtual communities enhance physical communities. In this context, the boundaries between real and virtual forms of communities gradually get obscure, and individuals regard their virtual community as real. In the digital age, the function of communication as value-based in virtual communities also functions to create physical communities as well (ibid).

In a study conducted to find out the immediate impact of the Covid-19 pandemic on mental health and quality of life among local Chinese residents aged 18 and older in Liaoning Province, mainland China, Zhang and Ma (2020) circulated an online survey through a social media platform between January and February 2020. Participants completed a modified validated questionnaire that assessed the Impact of Event Scale (IES), indicators of negative mental health impacts, social and family support, and mental health-related lifestyle changes. Zhang and Ma have concluded that the Covid-19 pandemic was associated with mild stressful impact in their sample, even though the Covid-19 pandemic is still ongoing.

A new type of coronavirus (Covid-19) has caused physiological as well as psychological and behavioural problems. Bahadır (2020) lists the effects of the 
global epidemic on the psychology of individuals as follows: "An individual's personality, age, socio-economic-cultural level, skills to cope with stress, values, philosophy of life, etc. depends on many factors. Fear of illness and death are the primary factors during an epidemic where uncertainty prevails. People are worried about the illness along with the death of themselves and of their relatives. They also want to maintain their strength, graduate from school, make a living and protect themselves from getting sick. Naturally, anxiety may increase if solutions to these issues are not created, for example, if they are furloughed in this process. Unnecessary and inaccurate information can increase anxiety and fear. A new lifestyle has begun to emerge, especially due to the processes of staying home. Needless to say, human is a social being. For this reason, the sense of restriction and isolation caused by lockdown can make one feel emotionally under pressure. Other factors that cause anxiety during the pandemic can be reduced by practising the following:

- To be informed about the correct sources of disease and virus protection.

- To learn and apply what needs to be done about hygiene

- Unnecessary and inaccurate information can increase anxiety and fear.

- Accessing the right information sources and making use of them.

- Limiting the time spent on social media.

- Creating a daily routine may bring about the feeling that life continues in its normal course. Sleep, nutrition, work, etc. schedule can be designed. However, if trying to comply with this program is also a problem, a more flexible program can be created.

- To make phone calls and video chats with relatives, family and friends who cannot be seen because of social distance. Hence, people can have the feeling that social life continues in another form.

As we see, the negative psychological effects of pandemic may appear. According to this we can see that informing people constantly, about hygiene, and sharing the information about pandemic cases and treatment methods and results help reduce public anxiety. In addition, since everyone is isolated in their own home in this process, presenting thoughts that will encourage people to cooperate and act together and create common feelings and motivation among people reduces social uncertainty and anxiety.

Important effects of a pandemic are the curfew and isolation of people. People feel lonely at home and alienated due to diminishing social interaction. Apart from the reactions to the epidemic, the responses to uncertainty and the ability to cope with stress, depending on the personality structure, person-to person, age (childyoung-adult-elderly), socio-economic and cultural situation, etc. can also vary depending on many other factors.

A common behavior we see in outbreaks is that we move away from rational solutions and quickly believe some myths spread through social media. Hearing unscientific comments and information pollution can cause a lot of fear in humans. Therefore, people should be informed frequently by the authorities. Repetition of the measures, the rational dimensions of the Corona virus outbreak, and the high 
morale of people are extremely important for success. These problems are leading all individuals and communities to the atmosphere of risks to which they cannot be immune and that they cannot foresee and control in any way. During this crisis caused by the pandemic, it is essential for governments and state institutions to manage the discourse and actions, viewpoints of events and ways of directing the society, which are very important for them to effectively manage the crisis process. At this point, the concept of value-based collaboration emerges.

Understanding cooperation means understanding how members use the language to share specific things. Organizational reality is thus created by using these language games. Understanding cooperation also denotes understanding the life structures of people inside organisations and how they influence the way members address and solve problems as well as how they are generally involved in organisational life (Jørgensen, 2004: 88).

Wittgenstein's concept of language games suggests that the positions, interests, intentions and strength of language games are described using Foucault's concept of power (Foucault, 1978, 1979 qtd in Jørgensen, 2004: 86). When used from a critical point of view, it is useful to emphasize how a certain change in discourse creates problems, methods and solutions that contain some specific ideas about who people are and why they think and do what they do (ibid). In Wittgenstein's conception, languages become a part of life and doing things essentially a part of everyday life. The meaning of language is understood by the work that the language is doing in social life.

According to Ethics Resource Center, value driven activities are defined by guiding principles, mission statements, moral standards for leadership, motivating people for value commitment (qtd in Wieland, 2005). During the process of the pandemic, the Turkish Minister of Health explained the principles and rules necessary for circumventing the pandemic and stated the rules and duties that each individual should do and follow individually on his Twitter account. In this process, he put forward the motivations that enable people to act together in cooperation with each other without alienation and invited people to contribute to the circumvention of the process. In this sense, we can see the performance of a value-driven activity. Society is a system like an organization and social practices are carried out within this system. Like many others, Turkey is a society that makes collective decisions and reveals it through collective discourse and practices with a related self-structure. In such a cultural structure, people do not become alienated from each other. For example, the various slogans put forward during this pandemic are; "stay at home," "we are good enough for us" etc. These statements have led people to act together. All in all, physical isolation was attempted to be overcome with emotional and intellectual integration.

Groddeck (2010: 70-71) discusses that all social systems encompass certain communication operations or rather the interconnection of communication events over time. The term "system" is employed to display how certain social formations are generated, which are stabilised by mutual relations, feedback and selfmanagement processes.

The term value has a long tradition in sociology, philosophy and economics. It grew very prominent at the end of the $19^{\text {th }}$ century, when early sociologists used it to 
discuss the question of societal integration. Because of an increasingly differentiated society with a less clear structure, the question arose as to what the society was holding together. The answer was seen in moral, social and cultural values, not in religious beliefs, as it was in the pre-modern society (Durkheim, 1973; Parsons, 1960 qtd in Groddeck (2010: 72). Talcott PARSONS formulates: "Values in this sense are commitments of individual persons to pursue and support certain directions or types of action for the collectivity as a system and hence derivatively for their own roles in the collectivity."

Values are not considered a fundamental condition for individuals or social entities that affect effectiveness. These are empirically observable forms of communication that show values only as invisible aspects of individuals or social entities and are evaluated as values by empirical applications, for example, by referring to corporate values, ethical standards, value learning programs to improve leadership skills, or just expressing the values, beliefs and drivers of managers. A specific phenomenon as a form of value communication is perceived as an operational solution to an operational problem in the organization. From a systemic theoretical point of view, the relationship between problem solving is based on the need for survival of the system that is organized here. If we ask for a function of value communication, the task will be dealt with by addressing value communication with the application and dealing with a specific reference issue and the phenomenon of value communication. The uncertainty of solving a complex organization and its surroundings can be treated as semantics through value communication. Values are an environment in which organizations can inevitably cope with the uncertainty that creates the synchronisedness of a large number of enterprise operations (ibid, pp. 74-76).

Value-based communication should be addressed more in the context of healthcare within the scope of this study. In this context, we should first define value in the context of value-based healthcare.

The concept of "value-based healthcare (VBHC) is getting more commonly used in public debate and the notion of "value" is frequently considered as "health outcomes related to realised inputs." Nevertheless, two important aspects must be taken into account (European Union, 2019):

1. European healthcare systems are based on the concept of solidarity. The Charter of Fundamental Rights of the European Union and the European Pillar of Social Rights secure universal access to affordable, preventive, curative and good quality healthcare in the EU.

2. There is no single definition of 'value' within value-based healthcare. The definition of value is subjective and what is considered valuable can differ between patients, clinicians, healthcare providers, policy makers or industry stakeholders.

In order to meet the challenge of ensuring the financial sustainability of universal healthcare and finding the resources to finance innovation, it is essential to switch resources from a lower value to higher value healthcare. The Expert Group proposes a comprehensive concept based on four value pillars to define 
"value-based healthcare" to convey the guiding principles of solidarity-based healthcare systems (ibid, p. 1).

Allocative Value: Equitable distribution of resources across all patient groups. Technical Value: Achievement of best possible outcomes with available resources.

Personal Value: Appropriate care to achieve patients' personal goals.

Societal Value: Contribution of healthcare to social participation and connectedness.

Value-based healthcare can be used to inform when deciding and contributing to the streamlining, availability and resilience of healthcare systems. Initiatives have now been undertaken to address the following areas:

- Reallocation of resources: Disinvestment for reinvestment Unwarranted variation defined as 'variation in the utilization of healthcare services that cannot be explained by variation in patient illness or patient goals'.

- Fighting corruption, fraud and misuse of public resources.

- Increase public value in biomedical and health research.

- Regulatory policies for better access to high-value (but costly) medicines

- Incentives for fairer distribution and more optimal use of resources (ibid, p. 1).

The Expert Panel (Expert Panel's Recommendations) understands the redistribution of care from low to high value as the highest necessity for sustainable and resilient European health systems. A long-term strategy is recommended to achieve a cultural shift that allows for the release of resources to re-invest in highvalue care and to effectively redistribute towards value-based health care, with a strong management system.

- Develop a long-term strategy for a step-by step value-based approach towards change of culture. This strategy should encompass the definition of a series of goals that support the long-term objective of change, moving forward in small steps (work plans), including the implementation and monitoring of effects by use of existing data sources and methodologies as well as the creation of mechanisms to further guide the direction of change towards high value care.

- Support Research \& Development on/of methodologies on appropriateness and unwarranted variation by exchanging robust methodologies for measuring and monitoring patterns of clinical practice, regional variation, appropriateness research, by stimulating data collections (incl. real world evidence and big data) and by defining and aligning goal-oriented outcomes that matter to patients.

- Encourage health professionals to take responsibility and feel accountable for increasing value in healthcare, which may require freeing resources from low-value care to reinvest in high-value care encompassing the 
training of "change agents" (leaders) that feel accountable for the health of the population, including equitable distribution of resources across diseases. Health professionals hold a key role in advocating a change of culture towards social cohesion and connectedness.

- Support the creation of Learning Communities, including communities of health professionals, to bring together the best expertise, experiences and practices, contribute to change of attitudes and to learn from each other by measuring, benchmarking and implementing actions across the EU. Member States should take the lead in identifying and pinpointing the most important tasks, the EC should create a supportive and facilitating environment for the establishment of those Learning Communities that will contribute to a change of behaviour and a change in legislation.

- Support initiatives for patients' engagement in shared decision-making, recognising the importance of patients' goals, values and preferences, informed by high quality information to implement empowering practices and goal-oriented person-centred care (ibid, p. 2).

\section{Community Building Function of Social Media in the Context of Twitter}

Developments such as the spread of the internet, the ability of individuals to interact and produce their own content on the internet have had important effects on the structure of communication. With the digitalization, changing the production, distribution, display and storage facilities of the media and transferring cultural products to the digital environment affect culture; transform all stages of communication. Trends such as increased interaction with social networks and the ability of the user to contribute to content production have not only led to the emergence of new forms of communication, but have also affected the consumption and production patterns of traditional media. In this context, Lev Manovich states that new cultural forms are emerging and cultural forms such as photography, television and cinema are being transformed and redefined. The ability of internet users to produce content in virtual environments, to share their comments, opinions, as well as the traditional media's one-to-many communication structure, have enabled the development of communication structures between peers, from one person to one, from many to many (Ateşalp and Başlar, 2015).

Henry Jenkins (Jenkins and Deuze, 2008) defines the change in communication environment through the concept of convergence. The phenomenon of convergence in the communication environment is more than just a technological change; it is a complex process with economic, global, social and cultural dimensions. Jenkins uses the concept of convergence to define content streaming across multiple media platforms, to collaborate across multiple media industries, and to immerse viewers who can migrate anywhere. Convergence points to a cultural shift that encourages consumers to seek new information and to make connections between scattered media content.

As a result of the rapid developments in computer technologies and communication networks, the internet has become an indispensable part of our lives. The process, which we call the technological paradigm by Castells (2008), 
radically changes almost every aspect of our lives such as economy, politics, social relations, and culture. The technological paradigm has revolutionized almost everything in the context of time, space and relationships, and it has created new patterns of perception and relationship. This transformation that the technological paradigm has revealed in social structures and movements has led to the expression of the society we live in as a "network society". This type of society, which is referred to as the network society, has started to transform the society structures by spreading to a very large part of the world very quickly unlike the previous society types (Castells, 2008). The internet, which was used only as a means of getting information and accessing information for the first time, has become a social communication tool with the widespread use of websites such as Facebook, Twitter, etc. which have been defined as social media, and continuous communication at home, at work, on the street in short, almost everywhere where human beings exist. It created a virtual society. The relationships and actors envisaged by the classical sociology for the social structure have now started to change size and function (Köseoğlu and Al, 2013).

While social media has an increasingly larger place in social life, it is also important for brands, non-governmental organizations and politicians. Brands, non-governmental organizations and politicians use social media for public relations. However, social media is considered as a public space and politicians use social media as a communication tool within the framework of public relations. Political parties, leaders or candidates generally use social media tools in order to provide information, increase voting rates by affecting voters' behavior, preferences and decisions, create resources, create information networks with internal and external groups, and increase political participation.

\section{Methodology}

\section{Purpose}

This study aims to analyze the reflection of the communication strategy concerning the global Covid-19 crisis, utilized by The Turkish Minister of Health, on the discourses on Twitter. This analysis will be based on Value-Based Communication. In addition, word relation matrix and cluster analysis were performed using data mining methods.

It should be pointed out that the healthcare communication about Covid-19 has been managed and thus the data shared by the Minister of Health all by himself. Therefore, there has not been a secondary data sharing or pronouncement about the respective pandemic by any other government organisations or institutions.

At this point, it might be helpful to provide brief definitions of description, analysis and interpretation. Firstly, description is highlighting what the data collected indicates and what results it produces according to the research question. Analysis; on the other hand, is uncovering the themes and meaningful relationships between these themes that are not seen directly in the data set through conceptual 
coding and classification. Descriptive analysis consists of four stages (Y1ldırım and Şimşek, 2018):

1. Creating a framework for descriptive analysis.

2. Processing the data according to thematic framework.

3. Identification of findings.

4. Interpretation of findings.

The question of "what a particular utterance or observation indicates" draws up the main function of interpretation. In data analysis, meaning comes to the fore. Highlighting the meaning depends on the interpretation of the findings within their environment (ibid.). Furthermore, Miles, Huberman and Saldana (2014) categorise the four the components data analysis as; data collection, data display, data condensation and conclusion: drawing / verifying.

According to the visual analysis approach; collected data is summarized and interpreted according to the previously determined themes. Data can either be edited according to the themes put forward by research questions or may be presented by taking into account the questions or dimensions used in interview and observation processes (Yıldırım and Şimşek, 2018). Moreover, discourse analysis is the examination of the language in use, which is an approach to the analysis of any semiotic event (Gee, 2014).

\section{Limitations}

Twitter API has some restrictions on pulling data from user profiles. One of the restrictions is that it can only receive 3200 tweets per day. Another limitation is that some tweets in the date range can be skipped during this process. Although the study universe has 505 tweets in this research, this number may be different for the reasons mentioned above.

\section{Universe and Sampling}

In this study, it is determined that the first tweet by the Ministry of Health regarding Covid-19 was posted in 25.01.2020. It was seen that 505 tweets were posted during this process. Purposeful sampling method was used to measure the Value-Based Communication of the Ministry of Health. "Purposeful sampling allows for deep study of situations that are considered to have rich information" (Yıldırım and Şimşek, 2018: 118). In the "Value-Based Communication" analysis of the study, the first 100 tweets of the Minister of Health that had interaction were taken as basis and the codings were made through these tweets. The parameters used in the interaction of tweets are specified as: "retweetCount $=$ count of retweets" and "favoriteCount = count of likes". The interaction rate was determined by taking the arithmetic average of these parameters. The tweets that had the most interaction are revealed utilizing the formula below. 


\section{Interaction Rate: $\frac{\text { retweetCount faworiteCount }}{2}$}

All of the 505 tweets were used for the word proximity matrix and cluster analysis on the discourses of the Minister of Health on Twitter. Descriptive research model (Yıldırım and Şimşek, 2018: 239) was used as the method in the study. Mixed research designs are also included in the research by using qualitative and quantitative methods together. A Twitter Developer Account was created to obtain the data. An API (Application Programming Interface) was acquired from Twitter to obtain the data. All tweets were obtained using the RStudio program via the API. With the same program, tweets were converted into data frame/tibble data format and made ready for analysis.

The purpose of this discourse analysis is to highlight the hidden content that is not visible at first glance. During the analysis, evaluations were made over the words that came to the fore according to the frequency ranges of the words. In this analysis, in cases where the same word differs by taking a suffix, they are combined as a single word. In addition, synonyms have been subjected to the same process.

Codings were performed on the NVivo 11 Pro program. The coding process was carried out manually by the authors of the article. Firstly, for the coding reliability, each researcher performed an individual coding process on the related data set. Pre-coding on the data set was evaluated by all researchers, and a specific coding system was created. In order to ensure the validity of the coding process and to reduce errors, the message classifications are set to certain standards. Content not relevant for the study is excluded from the coding process. All operations, analysis, and data visualization techniques, except for coding on text with NVivo, were done with the RStudio program.

Text mining is another approach used in this study. Text mining can simply be defined as the process of producing structural texts that contain information from large amounts of unstructured texts. In order to reveal meaningful expressions with the processing of texts, some steps such as data preprocessing and feature extraction should be performed. After these stages, the non-structural data are converted into a structural format for the use of the text mining method. In this way, meaningful information in large amounts of data is tried to be revealed. By using these meaningful data, various results can be reached that institutions or organizations will benefit from. Mathematical and statistical methods are on the basis of text mining methods. Text mining is also used in different areas such as author recognition, text classification, idea mining, emotion analysis, keyword extraction, natural language processing, title extraction, and relationship rule extraction (Kılınç et al., 2016).

In the study, text processing and analysis were done with the RStudio program. The text mining library included in the RStudio called "Text Mining Package" or "TM" was used. The following text mining processes were applied respectively. Converting data into a corpus, equalizing the text size (tolower), removing punctuation marks (removePunctuation), removing numerical expressions 
(removeNumbers), removing expressions such as conjunctions and prepositions (removewords stopwords: 'Turkish') -when clearing these words, a dictionary appropriate for the language used should be selected-, removing internet links (removeURL), removing unnecessary words as deemed by the author in accordance with the study (removewords), combining words that can mean the same to one word (e.g., İstanbul and İstanbul'da), and removing word spaces (stripwhitespace). Finally, with the "TermDocumentMatrix" function, a termdocument matrix has been created for the data set received from the tweets. In this matrix, all words are converted to values 0 and 1 and network diagrams of words are created. Finally, cluster analysis was performed with the "cluster_fast_greedy" algorithm in RStudio.

\section{Results}

Top 100 tweets of Health Minister with the most interaction regarding Covid19 were examined. In total, 782 codings were carried out. These codings include three main categories of Value-Based Communication and their sub-categories. The main categories are "trust", "person-oriented health actions" and "governance". The "trust" category has 7 sub-categories, "person-oriented health actions" has 10, and "governance" has 4 sub-categories. There are 21 sub-categories in total.

In the codings made according to the expressions on Twitter (Table 1), it was determined that there were 266 codes in the "trust" category, 337 codes in the "person-oriented health actions" category, and 179 codes in the "governance" category. In this value-based coding, it has been determined that expressions about "person-oriented health actions" come to the fore with $43.1 \%$. Secondly, it was revealed that the expressions about "trust" were at $34.0 \%$, and finally the "governance" category at $22.9 \%$. As we can see, person-oriented health actions take precedence, and the qualifications that should be in people-centred care are as follows: social value, meeting needs, informing patients, doctors and public about the pandemic, qualified health workers, rapid intervention, personal and technical values, distribution-based value and research.

Table 1. Main Categories

\begin{tabular}{|l|c|c|}
\hline \multicolumn{1}{|c|}{ Features } & Frequency & Percent (\%) \\
\hline Trust & 266 & 34.0 \\
\hline $\begin{array}{l}\text { Person-Oriented Health } \\
\text { Actions }\end{array}$ & 337 & 43.1 \\
\hline Governance & 179 & 22.9 \\
\hline
\end{tabular}

The other important element that emerges is governance. In this respect, governance value is part of the value based management which offers a holistic solution to achieve performance, focusing on three core components:

- The main objective of maximising value through the implementation of sustainable strategies. 
- The management of the value which focuses on factors related to the attainment of the primary objective, factors relating to management, organizational culture, communication, relations with the external economic.

- Social and natural environment; Performance assessment system indicators that reflect the creation of value (Oane et al., 2015: 107).

The third important finding is an element of trust. In other words, building trust between management and the public is significant. Here are seven tips for managers to build or rebuild trust introduced by Sabatier (2014: 3-5):

1. Take an inventory of your trustworthy behaviours.

2. Act with integrity.

3. Admit mistakes.

4. Straight talk: do not avoid difficult conversations or feedback; people have the righ to know what you think.

5. Be approachable.

6. Right wrongs and go the extra mile.

7. Hold people accountable: People need to understand the benefits and consequences of their actions or lack of them.

Firstly, when looking at the "trust" factor (Table 2), the prominent features are "continuous information" with $9.3 \%$ and "reciprocity" with $9.0 \%$. (The numbers were shared daily with the daily number of cases in order to prevent a crisis and panic in the public.) The next features that were determined are, "interaction" with $5.9 \%$ (interaction with the scientific board, patients, artists' posts about Covid-19) and "assuming responsibility" with 3.7\% (the minister of health assumed responsibility for the problems that arose). The least common "trust" features among the content used by the minister on Twitter were found to be "prioritizing quality" with $1.9 \%$ and "compliance with ethical standards" with $1.5 \%$.

In the second factor, "person-oriented health actions" category, the most dominant features are as follows: "social value" with 10.7\%, "meeting needs" with $8.3 \%$, "informing patients, doctors and the public about the pandemic" with $6.6 \%$ and "personal value" with $6.1 \%$. Other distributions emerge as "qualified health workers" with $2.6 \%$, "rapid intervention" with $2.3 \%$, "technical value" with $1.9 \%$, "early diagnosis" with $1.5 \%$, "distribution-based value" with $1.5 \%$, and "research" with $1.4 \%$. As seen, person-oriented health actions, social value, meeting needs and informing patients, doctors and the public about the pandemic as well as personal value emerge as the prominent factors. In this context, within the scope of the statements made on Twitter, it is seen that the expectations and needs of the public are taken into account and that the functions performed are fulfilled in accordance with these expectations and information is given. This indicates a necessity to enhance the capacities of hospitals, to acquire new technical tools needed, to increase the number of beds and breathing apparatus, and to provide continuous information about pandemic. 
Table 2. Sub-Categories

\begin{tabular}{|l|c|c|}
\hline \multicolumn{1}{|c|}{ Features } & Frequency & Percent (\%) \\
\hline Trust & 21 & 2.7 \\
\hline Dialog & 12 & 1.5 \\
\hline Compliance with Ethical Standards & 46 & 5.9 \\
\hline Interaction & 15 & 1.9 \\
\hline Prioritizing Quality & 70 & 9.0 \\
Reciprocity & 29 & 3.7 \\
Assuming Responsibility & 73 & 9.3 \\
Continuous Information & 11 & 1.4 \\
\hline Person-Oriented Health Actions & 12 & 1.5 \\
\hline Research & 12 & 1.5 \\
\hline Distribution-Based Value & 52 & 6.6 \\
Early Diagnosis & 18 & 2.3 \\
Informing Patients, Doctors \& the Public & 65 & 8.3 \\
About the Pandemic & 48 & 6.1 \\
Rapid Intervention & 20 & 2.6 \\
Meeting Needs & 84 & 10.7 \\
Personal Value & 15 & 1.9 \\
Qualified Health Workers & \multicolumn{2}{|l|}{} \\
Social Value & 57 & 31.8 \\
Technical Value & 15 & 3.4 \\
\hline Governance & 55 & 29.1 \\
\hline Openness & 52 & \\
\hline Accountability & \multicolumn{2}{|l|}{} \\
Participation of Stakeholders in the Process & \multicolumn{2}{|c|}{} \\
\hline Transparency & \multicolumn{2}{|c|}{} \\
\hline
\end{tabular}

Figure 1. Content Based Communication Categories

Content Based Communication

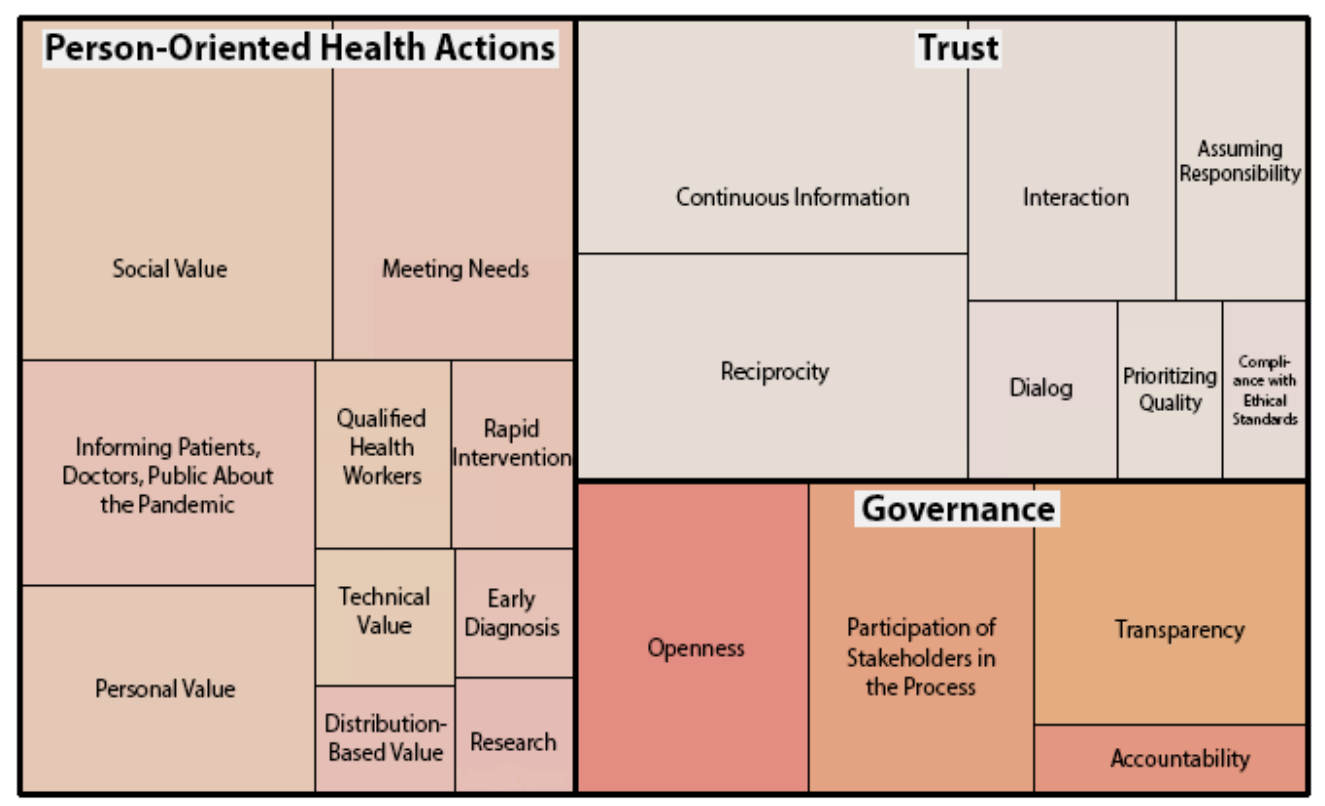


In the last factor, the "governance" category, the sub-category distribution rates are determined as "openness" with $31.8 \%$, "participation of stakeholders in the process" with $30.7 \%$, "transparency" with $29.1 \%$ and "accountability" with $8.4 \%$. The distribution of categories and sub-categories is shown descriptively in Figure 1.

Figure 2. Word Relationship Matrix based on the Twitter Discourse Analysis of the Turkish Minister of Health about Covid-19

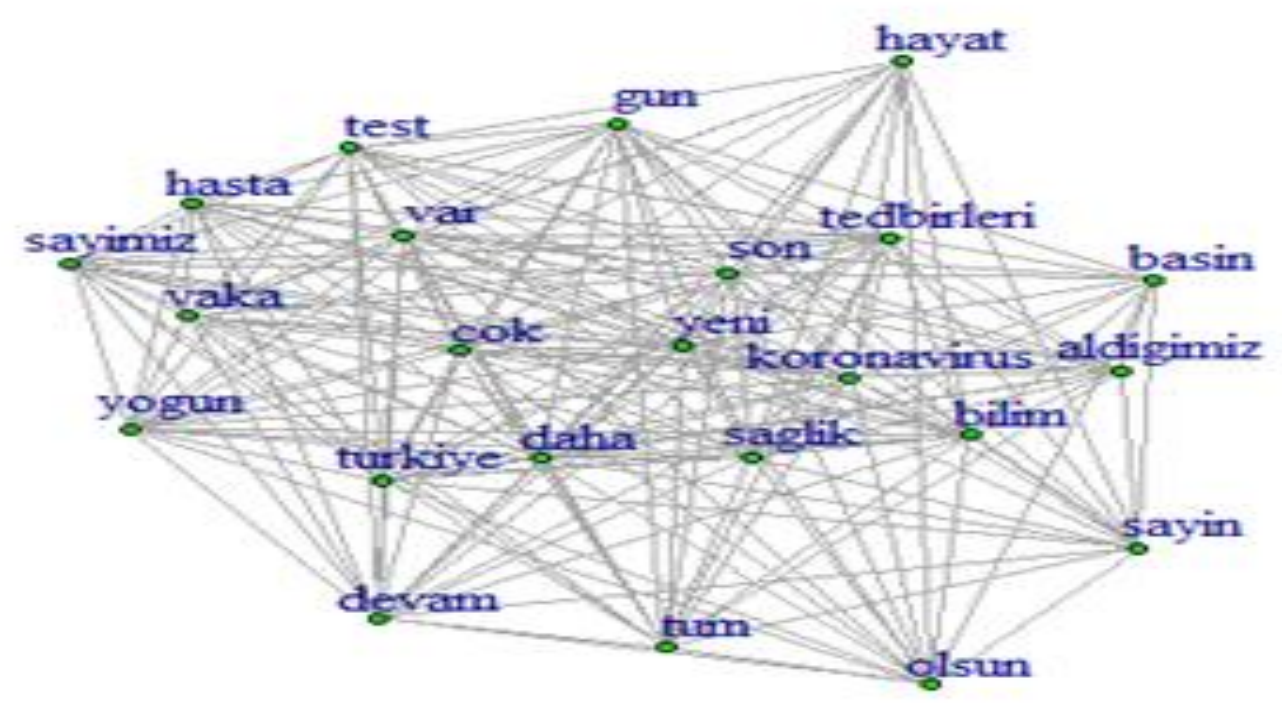

Figure 3. Cluster Analysis based on the Twitter Discourse Analysis of the Turkish Minister of Health about Covid-19

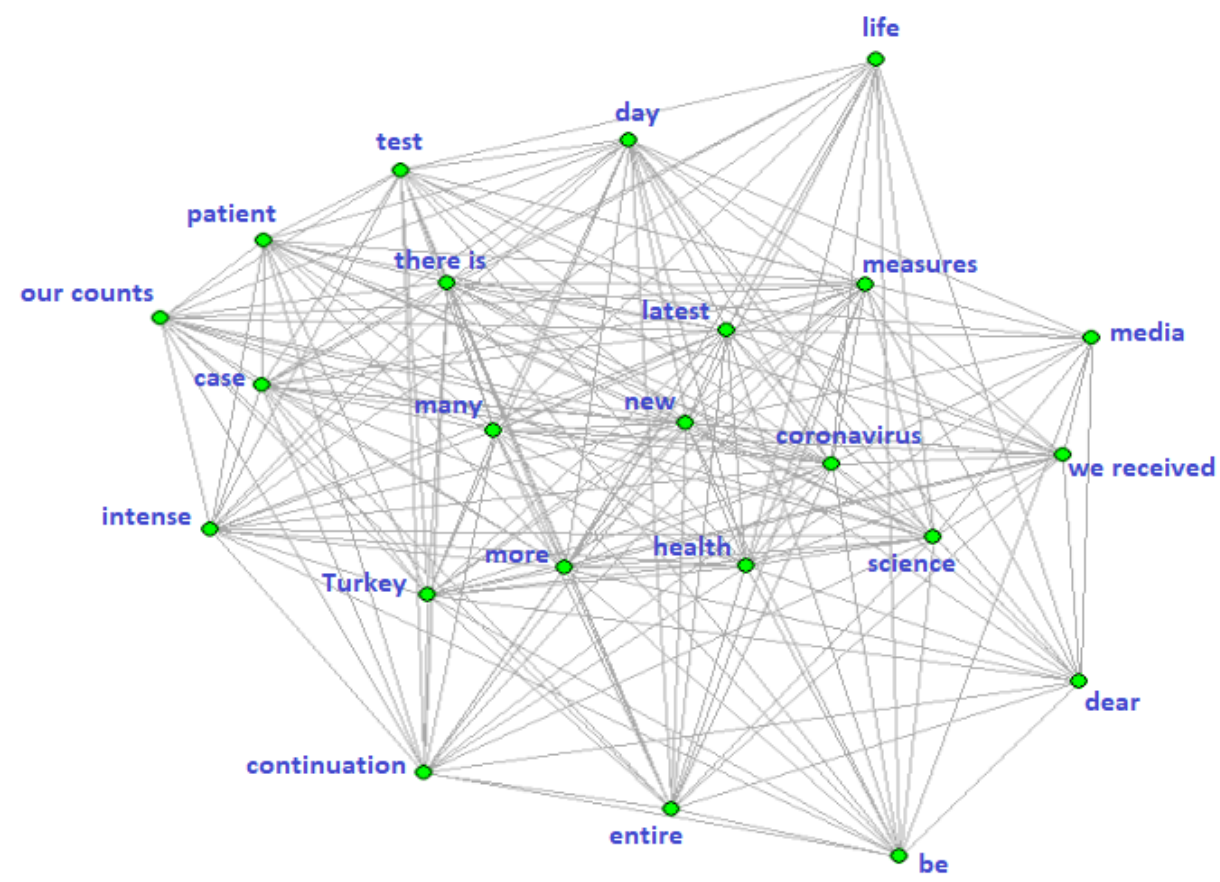



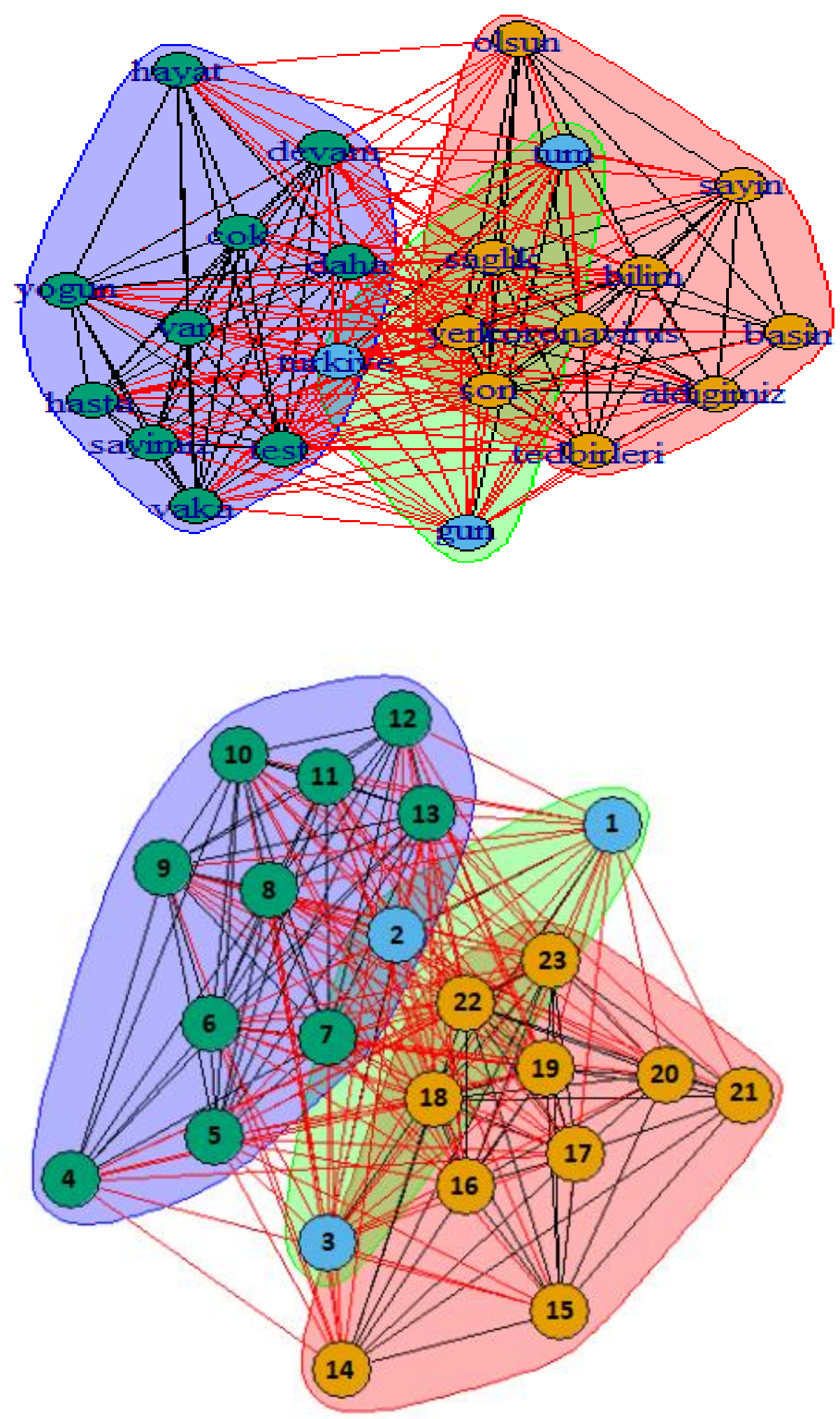
$\underline{\text { Blue }}$

1- Day

2- Turkey

3- All

$\underline{\text { Green }}$

4- Life

5- Continue

6- Many

7- More

8- There is

9- Intensive

10-Case

11-Patient

12-Number

13-Test

$\underline{\text { Yellow }}$

14-Let there be

15-Dear

16-Precautions

17-Science

18-Health

19-Coranavirus

20-The (precautions) taken

21-Media

22-New

23-Last

\section{Discussion}

Leaders try to create some behavior in the audience with the way they communicate, while trying to create understanding and relationships with the target audience. There are elements such as mutual dependence, satisfaction, empathy and trust in this relationship.

Satisfaction with communication seems to be more associated with communication focused on tasks such as relationship-based communication, because task-oriented communication is immediately rewarded by executing a task. As people focus more on remote communication than for personal communication, it is expected that, compared to communication to building relationships, communication focused on tasks shows a greater impact on satisfaction with communication (Marshall \& Novick, 1995 qtd. in Kang, Han \& Lee, 2017). Successful communication affects cooperation. Task-oriented and relationship- 
building communication consists of interdependencies, joint management and satisfaction with communication (ibid, p. 5).

Moreover, Bennis and Thomas (2002: 1-2) maintain that leaders create a sense of events and relationships that would otherwise go to waste without them. Even if the leaders are bothered by experience; they are not considered helpless and are not considered paralyzed. They look at the same events that encourage those less capable and happy, and see something useful and often a plan of action. An important part of our leadership model is what lies on the other side of the crucible-qualities that define lifelong leaders and learners. One of the main advantages that all our leaders share, whether young or old is their ability to adapt. The ability to process new experiences, find their meaning and integrate them into a person's life is the ability to designate leaders and truly anyone who finds ways to live fully and well.

On the other hand, Stein et al. (2013) assert that there is still a large transformation of people-to-human care services: the lack of clearly defined and measurable objectives, consistent communication strategies or participatory approaches in the development and implementation of integrated care are only a few shortcomings that can lead to partial shortcomings that may give way to optimal results or current challenges with a view to sustainable and large scale efforts. Ensuring implementation throughout the system often prevents ambiguous stimulus structures, the lack of suitably trained professionals and/or obsolete legal frameworks.

Quality movement and ergonomic movement have many basic similarities, such as the basic values on which these movements are built. The keywords shared between them are; "Human needs, expectations, requirements, comfort, health, happiness and satisfaction" (Axelsson qtd in Bäckström et al., 2014: 59).

Furthermore, as Bäckström et al. (2014, pp. 61-62) indicate, communicative leadership can be defined as openness, accountability and continuous dialogue with communities. Communicative behaviours of leaders encompass four aspects: "structuring, facilitating, relating and representing" Furthermore, engaging communities in dialogue, actively sharing and seeking feedback, giving importance to participative decision making.

Within the scope of this study, it can be stated that through Twitter, the number of pandemic-related deaths, the number of positive and negative issues, the developments in the health prompt, comparative rates of cases with different countries, treatment methods applied, research on vaccine, etc. have constantly been emphasized. In the same way, the issues such as openness, transparency and reliability have been stressed.

\section{Conclusion}

The beginning of pandemia communication is March 11, 2020, when the first Covid-19 case was announced, as in measures and combat. The Minister of Health has come to prominence in the disclosure of the measures taken since then and informing the public about developments in Covid-19 cases. It has been the right 
choice of communication on behalf of the government to assume that the Minister of Health is predominantly in the name of the government to announce information about pandemic to the public. The Minister of Health initially began making a statement from his Twitter account towards midnight, making the number of cases and deaths public (Türk tabipleri birliği - Covid-19 pandemisi iki aylik değerlen dirme raporu, p. 54).

Health care workers were applauded by the public every evening at $9 \mathrm{pm}$ to support health care workers during pandemics and to create a respect and appreciation for their service. In this way, it has been positive for providing moral support to health care workers. It has been through Twitter to receive this support from the public.

Daily statements about pandemics, which are regularly performed by the Health Minister, have become more organized since March 27, 2020. The tweets, which he went through towards midnight, were replaced by a press conference two days a week after science board meetings and table statements covering information such as new cases, test numbers, recovery and deaths (p. 55). It can be suggested that the health minister, as a leader, managed the pandemic crisis with appropriate communication within the general action plan.

It should also be mentioned that the communication carried out by the Minister of Health is generally a task-oriented communication. The Ministry of Health's communication via Twitter has been made to the idea of which words are most used, the relationship of words to each other and in which clusters they are gathered within the context of idea mining. This review is based on the main criteria and sub-criteria of value-based communication. In the network diagram analysis (Figure 2), it is aimed to show the relation density of the words with each other. The center of this network diagram is created by "health", "coronavirus", "science", "new", "end", "measures", "case", "have" and "Turkey" words. It is determined that other words are used frequently together with these words in the center. It is seen that the other words associated with the words in the center are, "life", "test", "patient", "our number", "intensive", "continuation" and "day". Finally, it was determined that the word matrix created in the cluster analysis (Figure 3 ) is divided into three clusters. It is seen that these clusters are in parallel with the three basic categories of Value-Based Communication. Lilac colored area can be said to represent the main category of "trust". The words "patient", "test" and "our number" match with the category of "continuous information". Rose color, on the other hand, can be said to be closely related to "person-oriented health actions". The words "we take", "measures", "coronavirus", "science", "health" can be interpreted together with "social value", "meeting needs", "personal value". It can be said that the green color is representing the "trust" main category with the words "all" and "Turkey".

There is also a similarity between the elements of value based communication and the elements of quality management value. Considering all these respected elements, we need to have a management approach that meets communicative leadership features.

It is seen that communication activities performed during the pandemic are carried out in accordance with communicative leadership. It is more difficult to 
convince and direct people due to anxiety and ambiguity seen in society during the pandemic process. To eliminate this anxiety and uncertainty, a persuasive communication must be applied in it carrying some regulations and collaborations and various rules. This value-based collaboration will make it easier to manage the crisis process. Within the scope of this study, the rhetorical elements that create value-based communication are taken into account. These rhetorical elements are the main and sub-criteria that makeup value-based communication. With this rhetoric, value-based collaboration can be created as a new form of governance. Some procedures, norms and standards are applied to control this collaboration. In this sense, collaboration enables the establishment of communication between people in everyday life practices to create mutual understanding between people. Value-based communication demonstrates personality focus, sustainable communication, trust and clarity. Within the scope of this study, it can be said that messages provided by the Minister of Health via Twitter are in line with the main criteria and sub-criteria of value-based communication and constitutes collaboration.

\section{References}

Ateşalp, S. T., Başlar, G. (2015). Debates on participatory culture in relation to TV dramas in social media: Kardeş Payı case. E-Journal of Intermedia, 2(1), 158-180.

Bäckström, I, Ingelsson, P., Johansson, C. (2014). Health related quality management values and key principles of communicative leadership - Are they the same? Quality Innovation Prosperity, 18(1) 59-72.

Bahadır, G. (2020). Pandemi sürecinin psikolojik etkileri virüs kadar hızla yayılıyor. (Psychological effects of the pandemic is spreading as fast as the virus). Retrieved from: https://bit.ly/2FbJ3RC. [Accessed 2 May 2020]

Bennis, W. G., Thomas, R. J. (2002). Geeks and geezers: how era, values, and defining moments shape leaders - How tough times shape good leaders - Working knowledge for business leaders. Retrieved from: https://hbs.me/3bzueUV 8. [Accessed 5 May 2020]

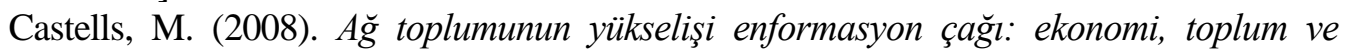
Kültuir. (The rise of the network society, information age: economy, society and culture). Turkey: İstanbul Bilgi Üniversitesi Yayınları.

Çoban, A. (2020). Koronavirüs salgınının psikososyal etkileri. (Psyho-social effects of corona pandemic). Retrieved from: https://www.cnnturk.com/saglik/koronavirussalgininin-psikososyal-etkileri. [Accessed 18 March 2020]

European Union (2019). Defining value in "value based healthcare". Report of the Expert Panel on Effective Ways of Investing in Health (EXPH). Luxembourg: Publications Office of the European Union.

Gee, J. P. (2014). How to do discourse analysis. London: Routledge.

Groddeck, V. (2010). The case of value based communication-Epistemological and methodological reflections from a system theoretical perspective. Forum Qualitative Sozialforschung, 11(3).

Jenkins, H., Deuze, M. (2008). Convergence culture. Convergence: The International Journal of Research into New Media Technologies 14(1), 5-12.

Jørgensen, K. M. (2004). Creating value-based collaboration: life forms and power in a change project. M@n@gement, 7(3),85-107. 
Kang, I., Han, S., Lee, J. (2017). Task-oriented and relationship-building communications between air traffic controllers and pilots. Sustainability. 9(10), 1-16.

Kılınç, D., Borandağ, E., Yücalar, F., Tunalı, V., Şimşek, M., Özçift, A. (2016). KNN Algoritması ve R Dili ile metin madenciliği kullanılarak bilimsel makale tasnifi. (Scientific article categorisation with the use of $\mathrm{KNN}$ algorithm and $\mathrm{K}$ language). Marmara Fen Bilimleri Dergisi, 28(3), 89-94.

Köseoğlu, Y., Al, H. (2013). Bir siyasal propaganda aracı olarak sosyal medya (Social media as a means of political propaganda). Akademik Incelemeler Dergisi, 8(3), 103125.

Miles, M. B., Huberman, A. M., Saldana, J. (2014). Qualitative data analysis - A Methods sourcebook. London: SAGE Publications Ltd.

Oane (Marinescu) C.M., Smolag K., Marinescu E.S., Szopa R. (2015). Value-based management as the innovating paradigm of contemporary governance - A theoretical approach. Polish Journal of Management Studies, 12(1), 106-120.

Sabatier, M. (2014). As a leader are you trustworthy? Building trust to transform team working. Development and Learning in Organizations, 28(5), 3-5.

Stein, V., Barbazza, E., Tello, J., Kluge, H. (2013). Towards people-centred health services delivery: a framework for action for the World Health Organisation (WHO) European region. International Journal of Integrated Care, 13(4), 1-3.

Szecsi, G., Koller, I. (2017). Community and morality in the digital age. Coactivity: Philosophy, Communication, 25(1), 18-25.

Türk tabipleri birliği - Covid-19 pandemisi iki aylik değerlendirme raporu. (Turkish medical association - bimonthly evaluation report). Retrieved from: https://www.ttb. org.tr/userfiles/files/covid19-rapor.pdf. [Accessed 28 April 2020]

Wieland, J. (2005). Corporate governance, values management, and standards: a european perspective. Business \& Society, 44(1). 74-93. 10.1177/00076503052748 52.

Yıldırım, A., Şimşek, H. (2018). Sosyal bilimlerde nitel araştırma yöntemleri. (Qualitative research methods in social sciences). Eskişehir: Seçkin.

Zhang, Y., Ma, Z. F. (2020). Impact of the COVID-19 pandemic on mental health and quality of life among local residents in Liaoning Province, China: a cross-sectional study. International Journal of Environmental Research and Public Health, 17(7), 112. 


\title{
A Critical Discourse Analysis of Language in Ghanaian Newspaper Editorials
}

\author{
By Justine Bakuuro * \& Africanus L. Diedong ${ }^{*}$
}

\begin{abstract}
The study explores the linguistic devices, approaches and styles in media discourse that are used to stake claims to knowledge, to influence attitudes and to promote critical thinking, among other functional roles of language. The study was equally interested in knowing the outcomes of the choice of these linguistic devices as far as communication is concerned. Linguistic devices such as modality, evaluative adjectives, adverbs, generic phrases, rhetoric and idioms among others, are used to state opinions, make predictions and influence attitudes. The study hypothesises that the study of language can be used in particular ways, so intended by the user, to achieve specific purposes. Eight different newspapers: The Daily Graphic, The Ghanaian Times, The Mirror, The Crusading Guide, The Insight, The Independent, The Catholic Standard and The Daily Guide, editorial excerpts were culled and used for the study of language use in newspaper editorials. The styles used and the reasons behind the choice of those devices and styles are closely looked at in the analysis. With Systemic Functional Linguistics, complemented with Van-Dijk's theory of Media Discourse as models of analysis, the study is theoretically anchored. The study concludes that editorial writers use linguistic devices to express different shades of attitude and opinion, to influence, shape or re-shape their readers' attitudes and to promote critical thinking of readers.
\end{abstract}

Keywords: Linguistic Devices, Media Discourse, Communication, Language, Styles.

\section{Introduction}

Language is the vehicle a person uses to convey his/her ideas about the world. It fashions out or polishes our attitudes and general behaviour. Language is a network of communication that helps one to assess his/her thoughts. We use language to convince and impact others, create humour and to display our love for one another. Truly, language is key to man's life and general existence. According to Opara (2011:1) 'language is essentially a way of behaving and making others behave'. With the help of language, we are able to express many opinions, ideas, emotions and attitudes. Additionally, it elicits a variety of ideas and feelings from the people we interact with in communication.

In the words of Finegan (2012:5), 'language is a vehicle of thought, a system of expression that mediates the transfer of thoughts from one person to another'. That means language enacts very vital roles in life since it is a way of social practice. It performs many communicative functions. It entails evidential or propositional information. Brown and Yule (1983:6) refer to this as the 'primarily transactional' role of language. They argue that in primarily transactional language, what the sender has in mind is the efficient and effective transmission of

*PhD Student, University of Ghana, Ghana.

${ }^{*}$ Senior Lecturer, University for Development Studies, Ghana. 
information. Therefore, the use of language in such a manner is message inclined while the function that has to do with the expression of social relations and personal attitude is deemed interactional, according to Brown and Yule (1983).

Finegan (2012) also envisages the basic role of language as connecting meaning to expression or usage as she puts it, 'Language is a vehicle for verbal expression of thoughts and feelings' (Finegan, 2012:5). Thus, language brings about innovativeness in the enactment process of communication. It is a tool of togetherness that binds us in our daily lives.

Language is used to express cogent and explicit ideas and beliefs which have the ability to change, implicate, convince and redirect the thinking of people in media discourse, particularly the print media. Language is portrayed as a catalyst for persuading and empowering people, taking into consideration the patterns of discourse in the Ghanaian print media.

In this regard, Alder and Rodman (2000:79) opine that "there is an intrinsic power in language to shape opinions and attitudes". The language that is used in the media equally expresses concepts, ideologies or at least, mirror human attitudes (Malcom, 1997).

Language novices do not seem to notice the power in language use which affects ideologies, moulds or remoulds conduct, attitudes or ideas. Moreover, they do not observe that language can negatively or positively affect public opinion or enhance critical reasoning and influence actions on critical current issues of our society. Often, this intrinsic power of language is either not noticed or is ignored by many people. Discourse in the media therefore gives people convincing thoughts which shape their opinions about issues affecting them.

This paper takes a look at the linguistic choices employed in selected Ghanaian newspaper editorials to express diverse opinions and attitudes and to spark critical thinking. It also seeks to scrutinise the way editorial authors engage these devices to examine the potentiality of state of affairs, influence people's opinion or belief and ultimately shape their attitudes towards happenings around them.

\section{Discourse Analysis and Newspaper Editorials}

Discourse analysis is 'the study of the ways in which language is used in texts and contexts' Nordquist (2013:1). Hence, it is simply a way of looking at the nature of language and how it is linked to the integral issues of society. Abrams and Harpham (2005) also posit that discourse analysis involves the use of language in a running discourse which involves the interaction of a writer and a reader in a specific situational context and within a framework of social and cultural conventions.

In general terms, one may see discourse analysis as a general term for a number of approaches to analyzing written, vocal or sign language use or any significant semiotic event. "Discourse analysis focuses on the meaning we give to people's words so as to make ourselves better, more humane people and the world a better place" (Norquist, 2013). Therefore, the analysis of discourse entails a close 
examination of the use of language and the implicitness of meaning in texts.

Newspaper editorials express ideologies and comment vividly on contemporary social, political, and economic issues. A discourse analysis which is based on social, political or economic ideology is a critical study. To this end, this study is a critical discourse analysis of the print media.

Weintraut (2013:1) asserts that an editorial is 'an article that presents the newspaper's opinion on an issue. Editorials are meant to influence public opinion, promote critical thinking and cause people to take informed decisions on issues of political, economic and social concern to society. For Shepherd (2013:1), an editorial is 'a way a reporter weaves his own personal opinion into a story'.

Still on editorials, Bilal et al. (2012:746) posit that editorials 'shape and build the ideology of their readers'. They reflect the opinion of a periodical since they are pieces of opinion documented by the senior editorial staff for publication in a newspaper or magazine. Editorials come in various forms. Hence, some explain or interpret sensitive or controversial issues. Some constructively criticize actions, decisions or situations and provide solutions to the problems identified. Editorials of persuasion aim at seeing immediately the solution and not the problem. Furthermore, well written editorials influence public opinion on current issues in the society. Weintraut observes that few editorials commend people and organizations for something well done (Weintraut, 2013).

\section{Research Objective}

This study seeks to explore how language, as the vehicle for communication, can be used to convey specific ideas as intended by the speaker or author to his/her audience. In this light, we are studying language as a manipulative tool which one can use to send intended, specific information as the sender so desires.

\section{Assumption of the Study}

Principally, the study thrives on the assumption that language is organic in nature and can be manipulated by the user to achieve intended goals. This hypothesis finds expression in Systemic Functional Grammar theory. The study therefore attempted putting this theoretical hypothesis to test with its analysis of newspaper editorials.

\section{Theoretical Underpinning}

The newspaper editorials analyzed in this study contain linguistic devices used for evaluation of issues, expression of opinions and attitude, and promotion of critical thinking as earlier indicated. Therefore, the Systemic Functional Grammar and Van-Dijk's theory of Media Discourse are relevant and most suitable in this study. 


\section{Systemic Functional Linguistics}

The major proponent of Systemic Functional Linguistics (SFL) is M.A.K. Halliday. Language, according to SFL, is a symbolic instrument used for communicative purposes (Malmkjaer and Anderson, 1991). SFL explains language from the way it is actually used in discourse and not just on the formal relations between linguistic units. Thus, language is viewed as a system of meaning potentials. Opara (2009:7) notes that 'funtionalists focus on the possible connection between form and function'. Therefore, systemic functional linguistics focuses on what people do with language. This study adopts the systemic functional approach to linguistics by depicting how linguistic patterns unravel ideologies, express opinions and attitudes, show persuasion and evoke critical thinking among others. The study further shows how the devices equally reflect opinions, shape or reshape ideas.

Systemic functional linguistics recognizes three meta-functions which are ideational, interpersonal and textual. The ideational function refers to the way language is used in expressing the realities of human experience.

Ajayi (2009:587) stresses that 'the ideational meanings relate to what is going on in the world, that is, how people use language to articulate experiences. They relate to how words are used to express actions, objects, places, events, people, things and ideas'. The interpersonal function gives individuals the opportunity to express their attitudes and establish personal and social relationships. This angle of function of language equally deals with how people express their judgment of social issues and how they use language to influence others. The textual function expresses the structure of information or how language is organized to achieve goals and to produce a cohesive text (Opara, 2009).

The ideational and interpersonal meta-functions are relevant to this study because the study examines how language is used to express human experiences in the editorials (ideational meta-function). Furthermore, the study portrays how language conveys attitudes, judgments and opinions in our contemporary world (interpersonal meta-function).

\section{Van-Dijk's Theory of Media Discourse}

The main tenet of this theory is that discourse analysis is an ideological analysis and that language gives meaning and meaning can be analyzed through discourse analysis. Van-Dijk (1998) stresses that ideologies are typically expressed and reproduced in discourse and communication.

This theory is relevant to the study since the analyses of the newspaper editorials help to bring out the underlying meaning of the linguistic devices used in the discourse.

Furthermore, Boyd-Barret (1994) states that the Media Discourse theory calls for a thorough analysis not only of the textual and structural level of media discourse but also for the analysis at the production or comprehension level. It implies then that the theory will allow us to do the deeper analysis of how understanding is crafted by the writers for the consumption of readers of these editorials. 


\section{Methodology}

Using the purposive sampling technic, we selected a total of 25 editorials from the eight sampled newspapers. These editorials were published daily or weekly over a span of time - August 2017 to April 2018. The editorials are culled from The Daily Graphic, The Ghanaian Times, The Mirror, The Crusading Guide, The Insight, The Independent, The Catholic Standard and The Daily Guide. Therefore, the data analysed in this study are editorial excerpts from the eight selected newspapers. The editorials were selected randomly and the relevant excerpts were copied verbatim. These data were subjected to content analysis based on the linguistic devices found in the editorials. The study is therefore a typical and critical observation of how language operates functionally to influence human life.

\section{Data Analysis}

Different linguistic devices were found in the newspaper editorials. Some of them were geared towards expression of different attitudes, promotion of critical thinking and expression of opinions and ideas to reshape attitudes among other social variables. Also, some devices showed the assessment of the potentiality of a state of affairs in the society and the statement of different claims. In this study, the focal elements of language which we set out to investigate include: use of modality, use of evaluative adjectives and adverbs, expressing modality using reporting verbs, use of generic phrases of modality, use of rhetorics and the use of idioms.

\section{Modality}

Modality is concerned with the writer's assessment of an attitude towards the potentiality of a state of affairs. It is a resource which writers use when they are staking claims to knowledge. Modality allows them to state different kinds of claims like assertions, opinions, hypothesis speculations (Cameron, 2001).

In the editorials, modal auxiliary verbs such as 'must', 'may', 'can', 'will', 'should', 'would', 'could', 'ought to', 'might', were used to express modality. The modal auxiliary verbs used in the editorials under study allowed the writers to attach expressions of belief, attitude and obligation to the statements they made.

The following excerpts depict the use of modal verbs:

1. Nonetheless, government should do something about the proliferation of these so called vigilante groups since that could easily undermine the peace we are currently enjoying.

2. The youth will undergo technical training in Information Technology so as to make them employable.

3. In spite of these minor chieftaincy disputes arising from time to time in various parts of the country, Ghanaians should be thankful to God for the 
peace and tranquillity in the country.

4. Parliament may rise anytime soon.

5. It could be inferred from the Minister's speech that the programme needs more funding.

6. The local government should take proactive measures to ensure that this is checked.

7. Our leaders should be advised on the need for periodic medical check-ups to forestall such occurrences in future.

8. This is cruel, and the offenders must face the wrath of the law.

9. Empowering young women will definitely boost the economy beyond imagination.

10. Sentences must be deterrent enough.

11. This will at least assure the victims that their attackers are going to face punishment.

12. We can hardly understand this move taken by Civil Society.

13. They might just have returned from their first leg of the World Cup qualifiers.

14. Parents ought to put an eye on their wards during the holidays to know the sort of moral training they are picking up from school.

15. It would interest the average Ghanaian to know these heart-breaking revelations about salaries and wages of government appointees.

16. This innocent girl would drop out of school.

17. People can continue to call us names but we will continue the fight until victory is ours.

18. It might have been one of the unsuspecting prostitutes that was shot in the process.

19. Ghana must work again.

20. The accident may have occurred in the early hours of Wednesday.

21. The man proved to be a warrior of his time but many say he could do better.

In the excerpts above, the writers, while reporting the contemporary issues at stake, express their attitudes towards the issues by using modal auxiliaries. They provided the information and went on to show their attitudes towards the events using these modal verbs.

In the excerpts, numbers $1,3,6,7,14,8,10 \& 19$ showed that certain courses of action needed to be taken as a matter of necessity and a certain level of compulsion through the modal auxiliaries 'should', 'must' \& 'ought to'. The extent of benefit those actions or inactions could yield on society are adequately expressed through these modal auxiliaries, bringing out the writers' attitudes to the events described. They also portray the obligations that actors in the particular events were expected to carry out. By painting this picture of obligation on the part of powers that be, the readers are stimulated to think critically about issues affecting them and to demand what is legitimately theirs. The editorial writers could have made their points without employing these modals, but their choice of them is to enable them convey specific intended messages. This is very much in 
tune with Systemic Functional Linguistics which sees language use as a process of making choices for specific purposes.

In excerpts $2,9,11,15 \& 16$, the editorial writers expressed predictions of future events or happenings using the modal auxiliaries 'will' \& 'would'. They appear to be certain about the happenings or events in question, applying their own intuitive abilities to judge issues in life. It therefore remains their opinion, which could be disputed anyway, that those events were going to happen. This is yet another expression of their attitudes towards the state of affairs presented.

The excerpts in 4, 5, 12, 13,17, 18, $20 \& 21$ express different angles of possibility through the auxiliary modals 'may', 'can', 'could' \& 'might'. How actors could take relevant steps to curtail, solve, enhance, ameliorate or control situations and events have been expressed by the writers using these modal verbs once again. This provokes critical thinking among the masses and speaks of the writers' attitude towards the state of affairs in the specific statements made.

In the foregoing analysis, we see the choice-based approach to language as entailed in SFL. The view that language is based on individual choices to arrive at various meaning potentials is clearly demonstrated with the writers' choice of modal auxiliary verbs. The writers could have used different verb forms if they intended to mean differently.

\section{Evaluative Adjectives and Adverbs}

The editorial writers employed some highly evaluative adjectives and adverbs as linguistic devices, again, to express their attitudes towards the pathetic state of affairs in the Ghanaian society. Some examples studied include:

1. In his usual pensive mood, the former president sat with his arms folded across his chest.

2. In such an atmosphere of profound disillusionment, circumspection as well as a large dose of intellectual humility is required on the part of those in charge.

3. President Nana Addo, of course, did not create the sorry state of modern Ghana.

4. At almost mid-term in office, there is still no urgent sense of crises.

5. The President does not help matters by pretending that everything is normal. For it is demonstrably not so.

6. They know from watching television and reading the newspapers every day that the seemingly elusive dividends of democracy have been cornered exclusively by a self-serving elite.

7. This means absolutely nothing to those in the majority who subsist on this meagre minimum wage a day.

8. Frankly, the political establishment should try and live on the minimum wage and see how much they can cope with its brutal reality.

9. It is precisely this lack of empathy that is so glaring and profoundly incompatible with the ethos of a democracy.

10. Needless to say, the insatiable greed that engulf government 
functionaries whilst they are still in office accounts for the vehement protests we see from opposition parties who feel they no longer belong to this nation.

11. Unexpectedly, the president lashed out at his political opponents in a strong-worded statement read by him on Wednesday evening.

12. We simply cannot afford to lose this great sense of nationhood bequeathed to us by our forebears under such reckless conduct.

The editorial writers did not only present some factual information of events in Ghana but evaluated the events through the use of the adjectives and adverbs marked bold in each excerpt above. The statements are indeed a revelation of some facts about the current socio-political terrain in Ghana. The reporters, again, have shown their attitude towards this state of affairs by their use of these descriptive terms. Adjectives and adverbs are descriptive word classes, and being descriptive, they aim at evaluating their objects described. Obviously, this situation is one that is unpleasant to the larger section of the Ghanaian society and this is made abundantly clear with the use of these evaluative terms. Other evaluative adverbs used in the editorials which have not been recorded as data are justifiably, famously, convincingly, ominously, unfortunately, indefinitely, primarily, promptly and technologically. Some adjectives which were not recorded as data: sad, incompetent, malicious, deviant, inalienable, absurd and ungovernable. These evaluative adjectives and adverbs succinctly portrayed different shades of attitudes as judgments by the writers. These attitudes were geared towards influencing opinions and promoting critical thinking on the part of the people.

Under this aspect of language use, Van Dijk's Media Discourse theory is brought to bear as the evaluative expressions basically aim at communicating a certain ideology to readers. As earlier stated, the state of affairs described by the writer is one of disgust. Therefore the deliberate use of these descriptive disgusting adjectives has the primary purpose of drumming home an ideology of an insensitive class of leaders who take the people for granted with their self-seeking attitude.

\section{Modality Through the Use of Reporting Verbs}

In the data collected, modality was again expressed through the use of certain reporting verbs such as claim, demand, expect, prefer and doubt. The reporting verbs reflected the editorial writers' opinions and attitudes towards the truth value of the content, that is, the extent to which they considered a proposition as true or false.

The Systemic Functional Linguistics principle of modality is expressed here since the choice of these reporting verbs is aimed at drumming home a particular message. Language as a meaning potential is here demonstrated by the use of reporting verbs to evaluate the truth value of propositions made.

Examples found in the editorials were:

1. Government claims that it is exploring the use of an electronic pipeline 
surveillance system to monitor oil theft.

2. We demand to know from the minister how much was spent on potable water provision by this administration in their first year in office.

3. One expects the people to weigh the serious consequences of cholera so that they would do everything possible to avoid it.

4. This association seems to have outstayed its usefulness and no longer champion or foster the interest of the masses.

5. In the period of Lent, every devout Christian was expected to understand more and know more about the faith.

6. Most Ghanaians would definitely prefer to pay for quality education than have a free one compromised in terms of quality.

7. The teaming youth of today doubt almost every policy by government largely due to infidelity on the part of past governments.

8. It appears most people are not enlightened on the TIN registration exercise.

9. It looks like the deputy minister goofed in the deal.

10. We suspect foul play in the death of one of our own here at the GNPC.

11. No one seems to support her recent comments on the CNN.

\section{Generic Phrases of Modality}

These are phrases beginning with expressions such as:

1. It is shameful that ...

2. It is equally cheering that...

3. It is good that...

4. We recognize that...

5. It is disheartening, however that...

The editorial writers revealed their opinions and judgments towards certain propositions through this form of modality as exemplified in the following excerpts.

1. It is disheartening, however, that this forum which is supposed to be an independent body of mature, responsible and knowledgeable elected political leaders, who contribute to national development, as a strong progressive body is now facing allegations of external manipulation by the President.

2. It is doubtful whether every Christian did derive the benefit that should accrue from the year of faith judging from the number that turned out at the various catechesis organized during the period.

3. It is shameful that without an account to the Ghanaian public or even an apology for that waste, the government is thinking of another money guzzling enterprise that may yet again, become a train pipe.

4. It is equally cheering that all regional health facilities in the country have been directed to provide free services to cholera patients. 
5. It is perilous for Ghanaians not to have access to potable water.

6. It is frightening and a shame to this administration that such basic hygiene problems still happen in the country in this age.

The editorial writers employed several linguistic devices to achieve modality to express their attitudes and opinions towards the truth of the propositions expressed in the sentences. To evaluate opinions about the described events, they employed modal auxiliaries, adverbs, adjectives, certain reporting verbs as well as verbs of knowledge and generic phrases.

We see the application of the SFL principle of modality at play here once again. As the theory argues about language as being meaning potential and based on the choices one makes, the editorial writers made these deliberate choices of generic modalities to realise the meanings that one can evidently derive from the statements.

\section{The Use of Rhetorics}

Another linguistic device used in the editorials was rhetorics. The rhetorics promoted critical thinking and produced a sharp effect on readers. The use of this device was more prominent in editorials that are ecclesiastical in nature.

Examples from the excerpts were:

1. Why should the country be subjected to such agonizing experience with its attendant socio-economic consequences?

2. Is it not a shame that in spite of Ghana's wealth and loud claims to civility and development, we cannot keep our youths in school for one uninterrupted academic year or more?

3. Why do wealthy Ghanaians prefer to send their wards abroad for tertiary education even to less endowed sister countries like Togo?

4. Is it not because their educational system is stabilized and they do what they have to do at every point in time?

5. Where are the so-called patriots when our country is sinking deeper and deeper in corruption?

6. Why won't they intervene promptly to nip corruption in the bud?

7. To what extent have the experience helped Christians who are victims of modern trend of atheism, secularism and syncretism to purge themselves of lack of faith?

8. Have the various catechesis and talks that featured during the year of faith translated to greater conviction in our doctrine and belief in the three persons in one God at times no matter what challenges are being faced?

9. To what extent has the year of faith enabled the various target groups to start performing their roles better than before?

10. What about Christians of various vocations and professions? How far did the past 12 months energize them to place Christ first in the discharge of their daily duties as a manifestation of their faith?

11. What difference has our exposure in the year of faith made in our people as a church or community? 
12. Those who used to take bribes, those who resort to divination or occultic means at the slightest challenge, have they stopped such practices? In other words has our faith been deepened?

13. If the regional boards cannot organize a free and fair election for themselves at their level, what do they expect to see at the district levels?

Clearly, rhetorics were used to influence readers and draw their attention to the state of affairs being discussed. The use of the device evoked emotional effects on the readers. The message is better drummed home with the use of this powerful communicative device as it emphasises the unpardonable nature of actions or inactions and the extent of absurdity in the state of affairs being reported.

The reader's sense of critical thinking is thus impressed upon by the writer's use of rhetorics.Van Dijk's media discourse theory applies here strongly as we are given the chance to tap into the understanding levels of the reader and the writer with the use of these rhetorics.

\section{Use of Idioms}

Palmer (2002:2) explains that 'idioms are a colourful and fascinating aspect of English'. Idioms were also used to describe events especially for thought provoking issues. The editorial writers make an attempt to tickle the minds of readers to think critically about the issues they put on the table. One may also argue that the use of idioms is a strategy by writers to attract readers since idioms are part of the spice of language. By this therefore, the writers validate their information to the reader, making the reader more likely to buy into the propositions and ideologies expressed in the editorials.

Some examples from the study include:

1. Despite the undue delay in paying the allowances, I believe it is better late than never.

2. Government over the last two weeks has been working hard behind the scenes to nip the strike in the bud.

3. Beating its chest, Government says that out of the key policy objectives, three critical ones have been tackled so far, citing Free SHS.

4. The country has clearly made $a$ wrong turn.

5. His demeanour that evening speaks volumes of the kind of person we have as our leader.

6. Our country continues to remain a shadow of itself in terms of realising the dreams of its founding father.

7. Most children throw up upon taking the cholera vaccine.

8. We must weather the storm to help the teaming masses of our nation who undeservedly are wallowing in abject poverty.

These idioms used in the editorials also added colour to the ideas presented. Thus, they have sharp, stronger meanings which sustains reader attention, thereby increasing their chances of being influenced by the attitudes and beliefs of the 
reporters and the people they report on. All these add to how language can be used as a tool to influence society and human life in general.

The impact of idioms in the study bears direct link to Van Dijk's media discourse theory in which he stresses the fact that media discourse analysis allows us to tap into the minds of the author and the audience to know their levels of understanding of the issues at table. The writer demonstrates sufficient understanding or knowledge of the state of affairs or information being conveyed by his ability to use idioms to depict reality about his ideology which he seeks to sell to his audience. The reader on the other hand is challenged by the fascinating, spicy language to endear himself to a better understanding of the ideology being communicated to him by the writer.

\section{Conclusion}

From the foregoing analysis, it is clear that the language of editorials is thought provoking, evaluative, persuasive and sophisticated. The editorial writers used different linguistic devices to achieve these. They used different linguistic devices in the form of modality, evaluative adjectives and adverbs, generic phrases, rhetorics, and idioms to express different shades of attitude and opinion, to influence, shape or re-shape their readers' attitudes and to promote critical thinking on the part of their readers. The writers used these devices to state different kinds of claims, and opinions, thereby assessing the potentiality of the state of affairs in the society and making judgments thereupon. To this end, language is seen as being influential: it indicts, persuades and empowers people. Language influences ideologies. This confirms the hypothesis of the study that language can be used in particular ways, so intended by the user, to achieve specific purposes. The editorial authors in this study have abundantly demonstrated this organic characteristic of the very nature and function of language.

\section{References}

Abraham, M. and Harpham, G. 2005. A glossary of literary terms. Cornell: Holt Reinhart and Winston.

Ajayi, H. 2017. English as a second language learners' exploration of multimodal texts in a Junior High School. Lagos: Lutron Publishers.

Aldler, R.B. and Rodman, G. 2016. Understanding human Communication. USA: Harcourt College Publishers.

Anigbogu N.C. 2015. Linguistic Devices in Media Discourse: A Case Study. International Journal of English Language and Linguistics.

Bilal, H.A., Rafaquet, U., Hassan, N., Mansoor, H. and Zahra, Q. 2012. Editorials of Pakistani English print media: Application of CDA. International Journal of Linguistics, 4 (3) 746.

Boyd-Barret, O. 2014. Language and media: A question of convergence. In: D. Graddol \& O. Boyd-Barret (eds). Media texts: authors and readers. (pp. 22-39). 
Brown, G. and Yule, G. 1983. Discourse analysis. Cambridge: Cambridge University Press.

Cameron, D. 2007. The teacher's guide to grammar. Oxford: Oxford University Press.

Finegan E. 2012. Language: Its structure and use. USA: Wadsworth Language learning.

Malcolm, X. 1997. Discovering language. In: P. Eschololz, A. Rosa \& V. Clark (eds.) Language Awareness. New York: St. Martin's Press, (pp. 11-15).

Malmkjaer, K. and Anderson, J.M. (Eds.) 1991. The linguistics encyclopaedia. London: Routledge.

Norquist, R. 2013. Discourse analysis. Retrieved from grammar.about.com/ord/d/g/disana lysisterm.htm.

Opara, S.C. 2009. Aspects of functional grammar: A systemic approach. Enugu: Victojo Production Services.

Opara S.C. 2011. Topics in discourse analysis. Owerri: Gabtory and Associates Ltd.

Palmer, F.R. 2002. Semantics. United Kingdom Cambridge University Press.

Sheperd, L. 2013. Writing tips for editorial. Retrieved from http://www.howtodothings. com/hobbies/94439-how-to-writ-an-editorial.html

Weintraut, A. 2013.Writing an editorial. Retrievedfromhttp://ww.geneseo.edu/bennet/Edw rite.htm

Wikipedia (2018). Discourse analysis. Retrieved from http://en.wikipedia.org/w/discour seanalysis

Google Scholar. (2018). Ghanaian Newspaper Editorials. Retrieved from http:/en.wikipe dia.org/wiki/editorial

Van-Dijk, T. (1998). Opinions and Ideologies in the press. Retrieved from http://www. howtodothings.com/hobbies/94439-how-to-writ-an-editorial.html1998 


\section{Appendix}

\section{Data Sources}

In table one, the source of each excerpt from the editorials used in this study is indicated. The serial number of each editorial excerpt is indicated in the first column of the diagram to the left in vertical order. The six different linguistic choices examined in the study are typed out in bold in the top first column of the table in horizontal order. Each box contains vivid description of the source of an excerpt: name of newspaper (e.g DGr), page (p.12) and then the date of publication (27/8/17).This is to make it possible for readers to verify the sources of the data.

Key:

GT=The Ghanaian Times,

DGr=The Daily Graphic,

$\mathbf{C G}=$ The Crusading Guide,

CS=The Catholic Standard,

TI=The Insight,

DGu= The Daily Guide,

TM=The Mirror,

TInd.=The Independent.

Table 1. Editorial References from Selected Newspapers

\begin{tabular}{|c|c|c|c|c|c|c|}
\hline $\begin{array}{l}\text { SN. of } \\
\text { Excerpt }\end{array}$ & Modality(21) & $\begin{array}{c}\text { Evaluative } \\
\text { Adj. \& } \\
\text { Adv.(12) }\end{array}$ & $\begin{array}{l}\text { Modality } \\
\text { via Rep. } \\
\text { Verb(11) } \\
\end{array}$ & $\begin{array}{c}\text { Generic } \\
\text { Modality(6) }\end{array}$ & $\begin{array}{c}\text { Use of } \\
\text { Rhetorics } \\
(13) \\
\end{array}$ & $\begin{array}{c}\text { Use of } \\
\text { Idioms(8) }\end{array}$ \\
\hline 1 & $\begin{array}{l}\text { GT,p14 } \\
27 / 1 / 18\end{array}$ & $\begin{array}{l}\text { TM,p21 } \\
17 / 3 / 18\end{array}$ & $\begin{array}{l}\text { CG,p7 } \\
5 / 9 / 17\end{array}$ & $\begin{array}{c}\text { DGu,p18 } \\
18 / 3 / 18\end{array}$ & $\begin{array}{c}\text { TI,p3 } \\
16 / 3 / 18\end{array}$ & $\begin{array}{l}\text { TInd.,p7 } \\
15 / 4 / 18\end{array}$ \\
\hline 2 & $\begin{array}{c}\text { DGr,p6 } \\
9 / 11 / 2017\end{array}$ & $\begin{array}{c}\text { GT,p3 } \\
13 / 11 / 17\end{array}$ & $\begin{array}{l}\text { TInd.,p13 } \\
\text { 18/11/18 }\end{array}$ & $\begin{array}{l}28 / 1 / 18 \\
\text { CS,p15 }\end{array}$ & $\begin{array}{l}\text { TM,p18 } \\
\text { 19/1/18 }\end{array}$ & $\begin{array}{l}\text { CG,p19 } \\
17 / 2 / 18\end{array}$ \\
\hline 3 & $\begin{array}{c}\text { CG,p11 } \\
28 / 12 / 2017\end{array}$ & $\begin{array}{c}\text { DGu,p9 } \\
8 / 2 / 18\end{array}$ & $\begin{array}{l}\text { CG,p22 } \\
3 / 12 / 17\end{array}$ & $\begin{array}{l}\text { TM,p6 } \\
\text { 4/8/17 }\end{array}$ & $\begin{array}{l}\text { GT,p18 } \\
30 / 1 / 18\end{array}$ & $\begin{array}{l}\text { TInd.,p11 } \\
\text { 23/11/17 }\end{array}$ \\
\hline 4 & $\begin{array}{l}\text { TI,p17 } \\
4 / 3 / 18\end{array}$ & $\begin{array}{l}\text { CG,p17 } \\
19 / 1 / 18\end{array}$ & $\begin{array}{c}\text { DGu,p19 } \\
14 / 1 / 18\end{array}$ & $\begin{array}{c}\text { GT,p9 } \\
27 / 11 / 17\end{array}$ & $\begin{array}{c}\text { TI,p23 } \\
14 / 3 / 18\end{array}$ & $\begin{array}{c}\text { CG,p9 } \\
29 / 10 / 17\end{array}$ \\
\hline 5 & $\begin{array}{c}\text { DGu,p14 } \\
18 / 3 / 18\end{array}$ & $\begin{array}{l}\text { TInd.p2 } \\
\text { 27/9/17 }\end{array}$ & $\begin{array}{c}\text { 19/10/17 } \\
\text { CS,p14 }\end{array}$ & $\begin{array}{l}\text { CG,p13 } \\
15 / 12 / 17\end{array}$ & $\begin{array}{c}\text { CG,p21 } \\
23 / 10 / 17\end{array}$ & $\begin{array}{l}\text { TM,p19 } \\
\text { 30/9/17 }\end{array}$ \\
\hline 6 & $\begin{array}{c}\text { TM,p17 } \\
27 / 10 / 17\end{array}$ & $\begin{array}{c}\text { TI,p14 } \\
20 / 8 / 18\end{array}$ & $\begin{array}{l}\text { TM,p8 } \\
6 / 3 / 18\end{array}$ & $\begin{array}{c}\text { TI,p19 } \\
12 / 2 / 18\end{array}$ & $\begin{array}{c}\text { DGr,p2 } \\
17 / 10 / 17\end{array}$ & $\begin{array}{l}\text { DGr,p14 } \\
21 / 11 / 17\end{array}$ \\
\hline 7 & $\begin{array}{c}\text { TInd.p44 } \\
5 / 9 / 17\end{array}$ & $\begin{array}{c}\text { CG,p11 } \\
7 / 3 / 18\end{array}$ & $\begin{array}{l}\text { DGr,p15 } \\
29 / 11 / 17\end{array}$ & & $\begin{array}{c}27 / 11 / 17 \\
\text { CS,p14 }\end{array}$ & $\begin{array}{c}\text { DGu,p4 } \\
4 / 2 / 18\end{array}$ \\
\hline 8 & $\begin{array}{l}\text { TInd.pp8 } \\
\text { 28/9/17 }\end{array}$ & $\begin{array}{l}\text { TInd.,p12 } \\
15 / 9 / 18\end{array}$ & $\begin{array}{c}\text { TI,p17 } \\
21 / 2 / 18\end{array}$ & & $\begin{array}{c}4 / 4 / 18 \\
\text { CS,p18 }\end{array}$ & $\begin{array}{c}\text { TI,p6 } \\
19 / 4 / 18\end{array}$ \\
\hline 9 & $\begin{array}{c}\text { TM,p9 } \\
16 / 1 / 18\end{array}$ & $\begin{array}{l}\text { DGr,p17 } \\
\text { 28/11/17 }\end{array}$ & $\begin{array}{c}\text { TI,p3 } \\
16 / 4 / 18\end{array}$ & & $\begin{array}{c}29 / 10 / 17 \\
\text { CS,p24 }\end{array}$ & \\
\hline 10 & $\begin{array}{l}\text { DGu,p10 } \\
29 / 12 / 17\end{array}$ & $\begin{array}{c}\text { DGr,p9 } \\
9 / 8 / 17\end{array}$ & $\begin{array}{c}\text { DGu,p12 } \\
25 / 3 / 18\end{array}$ & & $\begin{array}{c}\text { 20/9/17 } \\
\text { CS,p1 }\end{array}$ & \\
\hline 11 & $\begin{array}{c}\text { TI,p18 } \\
23 / 2 / 18\end{array}$ & $\begin{array}{c}\text { GT,p4 } \\
17 / 10 / 18\end{array}$ & $\begin{array}{l}\text { DGr,p20 } \\
24 / 10 / 17\end{array}$ & & $\begin{array}{l}17 / 1 / 18 \\
\text { CS,p10 }\end{array}$ & \\
\hline
\end{tabular}




\begin{tabular}{|c|c|c|c|}
\hline 12 & $\begin{array}{c}\text { CG,p7 } \\
30 / 8 / 17\end{array}$ & $\begin{array}{c}\text { TM,p8 } \\
29 / 10 / 17\end{array}$ & $\begin{array}{c}\text { DGu,p14 } \\
\text { 9/3/18 }\end{array}$ \\
\hline 13 & $\begin{array}{c}\text { DGr,p13 } \\
13 / 4 / 18 \\
\end{array}$ & & $\begin{array}{c}\text { TInd.,p13 } \\
12 / 8 / 17\end{array}$ \\
\hline 14 & $\begin{array}{l}\text { GT,p16 } \\
26 / 2 / 18\end{array}$ & & \\
\hline 15 & $\begin{array}{l}\text { TM,p6 } \\
3 / 10 / 17\end{array}$ & & \\
\hline 16 & $\begin{array}{l}\text { DGu,p15 } \\
20 / 11 / 17\end{array}$ & & \\
\hline 17 & $\begin{array}{l}\text { GT,p17 } \\
19 / 2 / 18 \\
\end{array}$ & & \\
\hline 18 & $\begin{array}{c}\text { TI,p1 } \\
15 / 4 / 18\end{array}$ & & \\
\hline 19 & $\begin{array}{l}\text { CG,p17 } \\
31 / 1 / 18\end{array}$ & & \\
\hline 20 & $\begin{array}{l}\text { DGr,p6 } \\
\text { 21/3/18 }\end{array}$ & & \\
\hline 21 & $\begin{array}{c}\text { TInd.p,9 } \\
2 / 4 / 18\end{array}$ & & \\
\hline
\end{tabular}





\title{
The Politics of Impunity and the Shifting Media Landscape in Kenya
}

\begin{abstract}
By Philip Onguny*
This article focuses on state-media relations and the shifts in the overall media landscape in Kenya. Drawing on a political economy approach to media operations in Kenya, it argues that while there are competing meanings over what constitutes "news values", "editorial independence", and "critical media", changes in political regimes and unclear media regulations contribute to political and/or corporate interference on media coverage of corruption and political impunity. This renders media operations problematic at the normative and operational levels. The discussion situates these arguments within the contexts of "policy laundering" and "critical junctures", seeking to establish whether the shifting media landscape is a function of increased information and communication affordability or, instead, an indication that critical media are on the decline. Overall, the article provides an assessment of key temporal periods that have shaped media regulatory frameworks to show how political and/or corporate interests have influenced journalistic practices and editorial independence over time and space.
\end{abstract}

Keywords: Kenyan media, media regulations, editorial independence, political impunity, policy laundering, safety of journalists, critical junctures

\section{Introduction}

Kenya has been perceived as one of the few African countries with a "pluralist" media, somewhat related to conditions under which media outlets operate. For instance, a recent report by Reporters Without Borders (2018) ranks Kenya $96^{\text {th }}$ (out of 180 countries) on World Press Freedom Index, a 4-point improvement from $2015^{1}$. However, according to the 2019 Corruption Perception Index by Transparency International, Kenya scores 28 out of 100 which highlights the slow progress in fighting corruption ${ }^{2}$. The same report places the average score in Sub-Saharan Africa at 32 and the global average score at 43. While Kenya's new constitution, adopted in 2010 following the 2007/08 post-election violence, recognizes the need for journalists to exercise their profession freely and responsibly, "a hostile and inadequate political, legal, policy and regulatory environment continues to negatively impact the media in Kenya" (Mbeke et al., 2010, p. 7). For instance, media coverage of insecurity, high-level corruption, and the past ICC proceedings against President Uhuru Kenyatta and his deputy William Ruto have been subjected to strict scrutiny by state organs (Mueller, 2014; Ogenga, 2013).

\footnotetext{
*Assistant Professor of Conflict Studies, Saint Paul University, Canada.

${ }^{1}$ For more details on the 2018 World Press Freedom Index, see https://rsf.org/en/ranking/2018. [Accessed on 25 August 2018].

${ }^{2}$ See Transparency International (2019). Corruption Perceptions Index, available online via https:// www.transparency.org/en/cpi/2018/results/ken. [Accessed on 18 July 2020].
} 
While it is true that "there is a relatively free media and general respect for freedom of expression" in Kenya (Kanyinga 2014, p. 11), there are several concerns with regard to political and corporate interference on media content, particularly on corruption and political impunity. At the centre of these concerns is how to protect journalists and their sources in an environment increasingly marked by high intolerance toward critical media. Although there are varying views on what falls within the purview of critical media, Fuchs (2010) reminds us that "an interpretation of media content is critical if the consumed form or content causes subjective insights that allow the recipients to question certain forms of domination, develop ideas of alternative models of existence that advance cooperation and can potentially guide transformative actions and social struggles" (p. 180). Based on this logic, some may attribute the presence/absence of critical media to formal institutionalization of norms and best practices determining journalistic practice (Benson, 2006; Couldry et al., 2010). However, this is not always the case in environments where formal institutionalization of such media practices exists alongside informal institutionalization. In such circumstances, one can certainly expect editorial independence to depend, to a large extent, not on media regulatory frameworks or policies in place, but on written and/or unwritten policies of the state as well as the political environment. This is particularly true in countries with high levels of corruption and political impunity such as Kenya, where several unwritten rules form part of the broader policies that determine media operations. These unwritten rules, often created through social-political bargaining processes, may translate into self-censorship, especially when threats and hefty fines are used as potential means to regulate media content on sensitive topics such as high-profile corruption and national security.

As one would expect, the resilience of journalists and editors in such environments is uncertain. In Kenya, the progressive disappearance of the Jicho $P e v u^{3}$ series, formerly aired on Kenya Television Network (KTN) serves as a good example. The Jicho Pevu series had become a household name, exposing a wide range of social, political, and economic impunities within the country, some of which involved individuals at high levels of the government (Kanyinga, 2014). Some of the topics covered included the alleged rigging of the 2013 elections, exposure of drug hauls involving key politicians and government officials, and the supposed cover-up of government failures during terror attacks at Nairobi's Westgate Mall and Garissa University. Given the prevalence of Jicho Pevu and the appeal it created around "digging up political dirt", some of its investigative journalists (e.g., Mohammed Ali and John Allan Namu) became subjects of constant death threats and harassment. Some describe such practices, where state/corporation interests interfere with media content, as a form of "media capture" or "state capture" (Wasserman, 2020; Schifrin, 2017).

While these observations provide important insights into the role played by state in influencing media operations, journalistic practices have also raised questions with respect to the institutionalization of political impunity. Authors such as Ireri (2016) have highlighted the prevalence of corruption in Kenyan media, arguing that "cash money (40\%) is the most common form of corruption-

\footnotetext{
${ }^{3}$ Jicho Pevu is a Swahili word for "critical eye" or "investigative lens".
} 
and politicians are the top bribe-givers to local journalists, followed by businesspeople" (p. 245). Other studies have also pointed out the problems of media literacy and insufficient training among journalists and how they compromise the overall quality of news media. This is the case of studies conducted by Mbeke et al., (2010) suggesting that, "media organizations (in Kenya) place a low premium on investigative journalism and hardly prioritize it" (p. 8). Further, the "poisonous rhetoric" circulated through new and/or interactive media have increasingly compromised the credibility of several journalists and their parent media outlets. These concerns may explain why the Kenyan government has been keen on enacting restrictive media policies over the years, particularly following election cycles which often turn violent.

For instance, following the aftermath of the 2007-2008 elections, the state proposed policies that allowed for the surveillance of text messages suspected of spreading hate messages. This extended to the use of information and communication technologies (ICTs) (Mitullah et al., 2015). Recently, concerns around the circulation of "fake news" in Kenya have also prompted questions on whether more policies are underway to curb online content (Posetti and Matthews, 2018). While untrue or false stories may have serious implications on public opinion, one emerging problem is that the state appears to capitalize on such circumstances to further infringe on freedoms of expression and on online media content. This means independent newsgathering, including the anonymity of journalists and their sources, can no longer be guaranteed because interested parties increasingly have the means to access the digital footprints. In fact, authors such as Mitullah et al., (2015) have pointed out that, "registration of SIM cards enables the government to trace sources of information and mobile phone signals" (p. 8).

This article focuses on the intersections between media regulations, statemedia relations, and the shifts in the overall media landscape in Kenya. It adopts a political economy approach (PEA) to show how the dynamism around media regulations in Kenya is closely aligned with the shifts in political regimes which, depending on the government in place, establish regulations and specialized state agencies that control media content. PEA is used to establish the linkages "between interests, incentives and institutions", and how they transform the overall media landscape (see Hudson and Marquette, n.d.).

The article argues that the fluidity characterizing Kenya's media regulatory framework not only contributes to the decline in editorial independence and critical news reporting, it also institutionalizes political impunity. The article begins by providing an overview of the media landscape in Kenya before focusing on media concentration and ownership patterns. It then shifts the focus to media regulatory frameworks and how they have informed journalistic practices over time. Finally, it situates these debates within the contexts of policy laundering (Hosein, 2006), journalistic field (Benson, 2006; Couldry et al., 2010) and critical junctures (McChesney, 2007). 


\section{Overview of the Media Landscape in Kenya}

Although the Kenyan media environment is considered to be resilient, dynamic, pluralistic, and somewhat critical $^{4}$, significant changes have taken place in Kenya's overall information ecosystem. Understanding this resilience requires an assessment of three temporal periods, which have marked important shifts in media practice. That is, the 1990-2000, the 2000-2010, and post-2010 media environments. More details about media environments prior to the 1990s are found in the works of Ochilo (1993), Faringer (1991), Moggi and Tessier (2001), Dixon (1997), and Okoth-Owiro (1990).

The 1990-2000 period was mainly characterized by strict state-led media control despite the reforms that saw the restoration of multiparty politics (Obonyo, 2003). For instance, political gatherings and media coverage of government activities in a negative light was almost always unlawful. In fact, until 1982, Kenya was regarded a de facto one-party state, and it was not uncommon for the parliament to establish laws with little to no consultation with media organizations (Widner, 1992). This seemed to be the approach the then ruling party (Kenya Africa National Union - KANU) took in its attempt to influence policies on media and on other issues of public concern (Obonyo, 2003, Widner, 1992). This provided the state-owned media - Kenya Broadcasting Corporation (KBC) - with the leverage as the primary source of information. As a result, the independent and privately-owned media that existed (e.g., Nation Media Group and The Standard Group) were confined to limited airwaves. It is worth noting that even though independent news media were stifled through restrictive media policies, commercial and political interest progressively infiltrated media operations, which provided foundation-level structures for grass-root opposition politics (Haugerud, 1995; Widner, 1992).

It was not until the 2000s (2000-2010) when the government embarked on ambitious political reforms which included a revision of the existing media laws/regulations. These reforms can be attributed to several factors. First, the end of Moi's 24-year authoritarian regime provided room to readjust policies on democratic and civil liberties that had stalled for several years (Shilaho, 2013). With the formation of a new government in 2002 (The National Rainbow Coalition, NARC), many expected to see a series of political and institutional reforms. However, since the anticipated reforms were slow to materialize, many accused the NARC government of rolling back the reforms they had promised the electorate once they ascended to power (Mueller, 2014; Shilaho, 2013). Second, the perceived deception by the NARC government was blamed, in part, for reviving inter-ethnic hatred, and the subsequent sensationalist media coverage of the 2007 election campaigns (Lynch, 2014). This is why recent studies suggest that the 2007-2008 post-election violence provided grounds for the state to amend self-regulatory bodies such as the then Media Council of Kenya (MCK) and Communication Council of Kenya (CCK), all of which were previously tasked with overseeing media practice (Sommerville, 2012). Third, the 2000-2010 period marked one of Kenya's worst ethno-political violence, as more than 1000 lives

\footnotetext{
${ }^{4}$ See Reporters Without Borders https://rsf.org/en/kenya. [Accessed 31 August 2018].
} 
were lost during the 2007-2008 post-election violence (Lynch, 2008). At the core of this violence were concerns about vernacular media's role in fomenting intergroup hatred before, during, and after the elections (Onguny, 2016). More importantly, the incentivization of violence by political elites became very apparent, which encouraged the establishment of a series of regulations aimed at curbing hate speech, political incitement, and inter-ethnic prejudices (Sommerville, 2012; Lynch, 2014). Moreover, with the confirmation of charges against Joshua Sang, one of the vernacular FM radio journalists, the 2000-2010 period raised questions with respect to professional journalism in the country. Nonetheless, the 2000-2010 period also saw a sharp and steady increase in the number of independent news media, particularly vernacular FM radio stations adding to media pluralism and diversity of opinions (Ogolla, 2011; Mbeke et al., 2010).

Finally, the post-2010 media environment has been characterized by a new constitutional dispensation, a notable effort in supporting democratic changes. In a sense, the 2010 constitution was a by-product of the 2007/2008 post-election violence and its aftermath. Although some may argue that its practical application is still a subject of debate, it is undoubtful that the document has attenuated political powers in the form of devolved government. The 2010 constitution also ushered in new media reforms in an attempt to put an end to sensationalist reporting, often driven by identity, personality, and ethnic politics (Shilaho, 2013; Lynch, 2014). Although the new regulations also sought to protect the media, the controlled coverage of the ICC proceedings against president Kenyatta and his deputy demonstrated that each political regime sets its own rules with respect to media operations (Mueller, 2014; Ogenga, 2013). Accordingly, the Jubilee government, which came to power in 2013, has been accused of using unwritten rules to control media discourse particularly on issues relative to political impunity (Shilaho, 2018; Lynch, 2014; Mueller, 2014). For instance, the consolidation of state's advertisements through the newly created Government Advertisement Agency represents one of the indirect ways in which the state ensures "media capture". That is, given the significance of advertisement revenues in media operations, the incumbent regime may have found a way to increase its leverage on media coverage of controversial topics implicating its officials (Media Policy Research Center, 2015; Muhatia, 2017). While it is reasonably true that the initiative may help the government reduce its spending, the agency uses its newlyfound monetary power to influence media content at the editorial level (Muhatia, 2017). As a consequence, news outlets perceived to be critical of the state have seen their ad revenues dwindle due to withdrawal of government advertisements. The post-2010 media landscape has therefore been marked by an increase in both formal and informal institutionalization of media regulatory frameworks.

Together, the three broad periods show how the media landscape in Kenya is relatively linked to changes in political regimes. If these patterns are indicative of anything, then one can certainly expect media regulatory frameworks to remain unstable in the long-term. Similarly, and owing to the steady growth of independent and commercial media, journalists and news editors will remain at a crossroads. They will constantly wrestle with the idea of adopting a more critical perspective on matters of political impunity and risk sanctions or taking part in the 
overall impunity process by accepting "brown envelops" in order to bury or water down certain news stories. Regardless of these choice alternatives, it is undoubtful that political impunity and corruption have risen to worrying levels (Shilaho, 2018; Schmidt and Deselaers, 2015).

\section{Media Reach and Concentration}

In order to understand the links between political impunity and the shifts in Kenya's media regulatory frameworks, it is worth discussing media reach and concentration more broadly. Such an overview is important not only because the distribution between media formats (e.g., radio, TV, newspaper, etc.) is unbalanced, but the impact these regulations have on different media is equally disproportionate. Admittedly, radio still remains the primary means of information despite the increase in the number of Kenyans with access to digital technologies. The annual statistics by the BBC Media Action (2017) show that 96-98\% of Kenyans have access to radio, followed by mobile phones at $95-97 \%$, then TV at $81-89 \%$ and finally Internet at $51-58 \%$.

The completion of the digital migration process in 2015 also brought about new forms of media experiences. According to the International Telecommunication Union - ITU (2017), digital migration saw the population covered by TV grow from $55 \%$ to $66 \%$. The same report shows that the number of broadcasters increased from 14 to 65 , with about 22 broadcasters reaching multiple cities (up from just 5). The growth also indicate that the Kenyan media sector is increasingly becoming expansive and diversified in terms of content, all of which tilt the patterns of media concentration and ownership. To date, seven media houses remain the most dominant. These include Nation Media Group, Standard Media Group, Royal Media Services, Radio Africa, Kenya Broadcasting Corporation, and TV Africa Holdings. One common factor is that the majority, if not all, are controlled by political elites or influential entrepreneurs who, in one way or another, are linked to the current or previous governments. The concentration of media in the hands of few elites is however nothing new. As Ogola (2015) reminds us, "the exponential growth of the media (particularly in the 1990s) saw the emergence of the so-called 'gutter press' - publications that were often funded by politicians to malign their adversaries, ruin reputations or settle scores" (pp. 9596).

Media ownership patterns have therefore remained relatively the same, with elite-centered media oligopolies. For example, the Royal Media Services, owned by businessman Samuel K. Macharia, controls almost all privately-owned ethnic/vernacular radio stations (at least 14 vernacular FM stations), including dominant news outlets such as Citizen radio, Hot 96 FM, Citizen TV, and iNooro $\mathrm{TV}^{5}$. Kenya Broadcasting Corporation, on the other hand, is a state-run media group, which oversees KBC TV, KBC Radio, y254 TV, Coro-FM, Ingo-FM, Mayienga-FM, Pwani-FM, Kitwek-FM, Iftin-FM, among others ${ }^{6}$. The largest (in

\footnotetext{
${ }^{5}$ See https://www.royalmedia.co.ke. [Accessed 28 August 2018].

${ }^{6}$ See https://www.kbc.co.ke. [Accessed 18 July 2020].
} 
terms of circulation) and probably the most influential media organization is Nation Media Group. It is also the second oldest media group after the Standard Media Group. Owned by philanthropist The Aga Khan, Nation Media controls Daily Nation newspaper, Nation Television (NTV), Spark TV, the East African, Taifa Leo, Easy FM, K-FM, Dembe-FM, the Monitor (Uganda), among others. The group owns at least eight print newspapers, five broadcast media, and four online/digital media subsidiaries ${ }^{7}$.

The Standard Media Group is the oldest media organization and second largest in terms of concentration. It is controlled by the retired president Moi, his family, and business affiliates. The group owns popular TV stations such as the Kenya Television Network (KTN), Bamba TV, Farmers TV, the Standard newspaper, the Nairobian, Radio Maisha, Vybez Radio, Spice-FM, and Think Outdoor, an advertising company ${ }^{8}$. Other significant media houses include TV Africa holdings, which is under the purview of Kenyatta's family and affiliates. They oversee K24 TV, People Daily, and Kameme FM. Radio Africa Group, coowned by businessman Kiprono Kittony, is also an important media outlet in the country. It controls at least six radio stations (Classic 105, Radio Jambo, Kiss 100, Relax FM, East FM and X FM) a TV station - Kiss TV and a newspaper - The Star Newspaper. Other notable media owners include philanthropist Chris Kirubi who owns Capital FM, one of the most popular urban radio stations in the country.

In short, although media ownership in Kenya displays competitive and dynamic tendencies, a close examination of media concentration and ownership patterns not only shows the extent to which the Kenyan media are in the hands of a handful political elites; it also highlights the fluidity around media regulations, particularly during elections when political and corporate interests largely infiltrate news media. A potential explanation for this is that different media outlets often have a tilt toward specific political candidates and/or parties. Given this, it is undoubtful that commercial and political interests drive the growth, ownership patterns, and media regulatory frameworks in the country.

\section{Media Regulations and the Shifts in Journalistic Practices}

The changing media landscape has also impacted journalistic practices over time and space. Prior to the 2010 constitution, section 79 of the previous constitution remained the primary framework around which media operations were grounded (Moggi and Tessier, 2001; Okoth-Owiro, 1990). This was supplemented by several Acts such as Defamation Act, Public Order Act, Information and Broadcasting Act, The Books and Newspapers Act, Kenya Broadcasting Act, and Official Secrets Act, most of which were unfocused and/or vague (Ogbondah, 1994; Obonyo, 2003; Ogola, 2011). As some have pointed out, these laws relied upon pre-independence Statutes, which, for the most part, did not encourage critical media (Mbeke, 2008; Oriare and Mshindi, 2008).

\footnotetext{
${ }^{7}$ See https://www.nationmedia.com/brands/. [Accessed 18 July 2020].

${ }^{8}$ See https://www.standardgroup.co.ke/our-brands. [Accessed 18 July 2020].
} 
Section 79, "Protection of Freedom of Expression", which guided freedoms of speech and freedom of media until the 2010 constitution read:

Except with his own consent, no person shall be hindered in the enjoyment of his freedom of expression, that is to say, freedom to hold opinions without interference, freedom to receive ideas and information without interference, freedom to communicate ideas without interference (whether the communication be to the public generally or to any person or class of persons) and freedom from interference with his correspondence (Article 79, The Constitution of Kenya, 2001 - revision of 1998 version).

While there is nothing indicative of malice in the above clause, what is interesting to observe is the vagueness and broadness of subsections 79a, 79b and $79 \mathrm{c}$, which suggested the outlined freedoms could be revoked for the "interests of defence, public safety, public order, public morality or public health" (79a); or for the "purpose of protecting the reputations, rights and freedoms of other persons or private lives of persons concerned in legal proceedings, preventing the disclosure of information received in confidence, maintaining the authority and independence of the courts or regulating the technical administration or the technical operation of telephony, telegraphy, posts, wireless broadcasting or television" (79b). The said freedoms were also threatened if an individual "imposes restrictions upon public officers or upon persons in the service of a local government authority, and except so far as that provision or as the case may be, the thing done under the authority thereof is shown not to be reasonably justifiable in a democratic state" (79c).

Understandably, the broad scope of section 79 provided more wiggle room for successive governments to conveniently interpret what constituted violations of "national security", protection of "reputations, rights and freedoms of others", etc. As some pointed out, section 79 did not explicitly mention media practice thereby providing the state with the powers to limit editorial independence (Mbeke, 2008; Moggi and Tessier, 2001). In particular, it was unclear what defined/constituted media and journalistic practice. In addition to invoking the interests of national security as grounds to contain political dissent, the issuance of broadcast license was limited to a handful of media organizations for easy monitoring by state agencies. This, in part, discouraged media growth in the 1990s and early 2000s (Mbeke, 2008; Oriare and Mshindi, 2008). However, despite the restrictive media environment, investigative journalism was on the rise, keeping the public abreast of issues of public concern such as high-profile corruption by state bureaucrats and corporate elites. The uncovering of the Anglo Leasing Scandal, implicating retired president Moi and several other cabinet ministers within the Kibaki government, is a good example of the early beginnings of investigative journalism in the country (Bachelard, 2010; Okoth, 2016).

As Bachelard (2010) observes, Anglo-Leasing involved a US\$35 million scandal unearthed by John Githongo, then Permanent Secretary of Governance and Ethics, but whose inquiry was blocked by the Kibaki government. Despite the state's reluctance to tackle issues of corruption by senior state bureaucrats, public support for investigative journalism and critical media continued. However, it also 
became common for journalists and whistle-blowers bringing such topics to public's attention to face intimidation, hefty fines, and attacks (Jarso, 2010; Helander, 2010; Oriare and Mshindi, 2008). Although NARC government gave high hopes for reforms following the 2002 elections, media operations were still guided by the broad section 79 of the old constitution, at least until 2010 when Kenyans adopted a new constitution. NARC government used the broad regulatory framework to control media content on issues such as the abuse of power. This was the case in 2006 when the police stormed into The Standard Group buildings at night, seizing broadcast equipment and burning newspaper copies to prevent their circulation the following morning (Ogenga, 2013; Ogola, 2015). This sat at odds with the anticipated reforms and served as a reminder that the media environment under NARC was not any different. In fact, no major media reforms took effect until the early 2008 , following the $2007 / 08$ post-election violence.

Although the state's media capture continues to be a worrying trend, journalistic practices have also eroded over the years due to "the prevalence of corruption in journalism in Kenya" (Ireri, 2016, p. 245) and, to some extent, lack of professionalism in journalistic practices. Obviously, this is not the case for all media organizations. As Mbeke, Ugangu and Okello-Orlale (2010) observe, "large media organisations such as Nation Media Group, Standard Group, Royal Media Services and Radio Africa produce products and services that indicate a high level of professionalism" (p. 28). Given this, it would be false to suggest that the continued strains put on media operation are purely due to the poor levels of journalistic professionalism. Nonetheless, the growing infiltration of political and corporate interests in the determination what is newsworthy is worrisome.

In terms of media regulatory bodies, two "independent" organs guided media practice up until 2013: Communication Commission of Kenya - CCK (now Communication Authority of Kenya) and Media Council of Kenya - MCK (with amendments in 2013). CCK's mandate included, among others, the licensing of telecommunication services, approval of communication equipment, management of radio frequency spectrum, and implementation of universal service obligations for telecom and postal services (Mitullah et al., 2015). Although the Commission identified itself as an independent body, most of its activities were supervised by the former Ministry of Information and Communication. It is therefore not surprising that licencing privately-owned media was selective, with audience reach limited to select urban areas. MCK, on the other hand, was mandated with the task of setting the standards of journalistic practice. On a broader scale, MCK acted as an arbitration body between the media, the public and the government.

With the adoption of the 2010 constitution, the parliament adopted a series of relegations in 2013 which saw changes in the existing media governing bodies. Among them were the Kenya Information and Communication - Amendment Act (KICA) and Media Council Act, which amended the operations of CCK and MCK by establishing the Communication Authority of Kenya (to replace CCK) and Media Council of Kenya (with a revised mandate). These Acts supplement Articles 33 (freedom of expression), 34 (freedom of the media), and 35 (access to information) of the 2010 constitution, all of which target media practice. Article 33 
provides that freedom of expression does not allow the circulation of content that promotes "propaganda for war; incitement to violence; hate speech; or advocacy of hatred that - constitutes ethnic incitement, vilification or others or incitement to cause harm; or is based on any ground of discrimination" ${ }^{\prime 9}$. Article 34, on the other hand, observes that "the State shall not - (a) exercise control over or interfere with any person engaged in broadcasting, the production or circulation of any publication or the dissemination of information by any medium; or (b) penalise any person for any opinion or view or the content of any broadcast, publication or dissemination"10. Finally, Article 35 states that "(1) every citizen has the right of access to - (a) information held by the State; and (b) information held by another person and required for the exercise or protection of any right or fundamental freedom"11.

Whereas these regulations provide some clarity with respect to contemporary media operations, the arrival of the Jubilee regime in 2013 has brought with it new changes in media and journalistic practices. Because Kenya has been the victim of numerous terrorism attacks in recent years, the Jubilee government has enacted policies around the dissemination of information on terrorist attacks, including public access to and use of government information or records. The Access to Information Law signed by President Uhuru Kenyatta in 2016 is indicative of these changes ${ }^{12}$. Although it is unquestionable that taking measures on news content generating unwarranted public fear is necessary, such measures, if left unchecked, create incentives for repressive media bills/Acts. In fact, recent reports suggest that the adoption of policies limiting media coverage of insecurity has largely contributed to decline in Kenya's Media Freedom Index since $2013^{13}$.

While it is also true that such normative indexes are subject to mixed interpretations, what is certain is that media coverage of the government in a negative light (e.g., covering police brutality) often culminate into tight media regulations and attacks on journalists. For example, media coverage of terrorist attacks at Westgate Mall and Garissa University in 2013 and 2015, which exposed government insufficiencies in matters of domestic security, soured state-media relations at a time when issues of insecurity continue to dominate national politics (Onguny, 2020). The exposure of the lootings perpetrated by the defence forces at Westgate Mall while securing the premises was also deemed "insightful" or "propaganda" by the state despite video evidence (Robertson et al., 2013; Zadock, 2013). These are few of the many examples that show the delicate balance between factual reporting and avoiding what the state deems as incitement. Recent clampdown on journalists who publicize the number of Kenyan deference forces killed in Somalia also highlights the growing use of "unwritten rules" to limit media coverage of security-related issues (Einashe, 2016). National security is

\footnotetext{
${ }^{9}$ See Constitution of Kenya, Article 33(2) "Freedom of expression" http://www.klrc.go.ke/index.p $\mathrm{hp} /$ constitution-of-kenya/112-chapter-four-the-bill-of-rights/part-2-rights-and-fundamental-freedom s/199-33-freedom-of-expression. [Accessed 20 March 2019].

${ }^{10}$ Ibid, Article 34.

${ }^{11}$ Ibid, Article 35.

${ }^{12}$ The details of this Act can be found here: https://www.cuk.ac.ke/wp-content/uploads/2018/04/Ac cess-to-Information-ActNo31.pdf. [Accessed 20 March 2019].

${ }^{13}$ See Reporters Without Borders https://rsf.org/en/kenya. [Accessed 30 August 2018].
} 
often used as an excuse to limit journalists' coverage of inefficiencies in internal insecurity.

The highly contested general elections in 2017 and subsequent nullification of the presidential results also add to the worrying political interference in media. The switching off of the signals of major TV stations (e.g., Nation TV, Kenya Television Network, Citizen TV, and live K24) and their subsidiary radio stations in 2018 highlights this concern (Burke, 2018). Worse, with accusations of bias coverage from both the opposition and the incumbent government, journalists and news editors remain the primary targets of harassment, intimidation, and physical attacks, most of which are perpetrated by the police and military forces (Einashe, 2016; Ogola 2015; Onguny, 2016). Policing online content has also increased in recent years to reduce the circulation of hate messages online (Posetti and Matthews, 2018). Unfortunately, independent news bloggers covering the state in a negative light have been the primary targets of police brutality ${ }^{14}$. In a sense, these dynamics force journalists and news editors into cooperating with the state in exchange for "freedom".

Overall, these examples not only show the dilemmatic state-media relations; they also highlight the recursive influence between media environments and journalistic practices. This, of course, is not anything new. A number of studies, including those specific to Kenya, have shown how media environments influence the journalistic field. Lohner et al. (2016), for instance, emphasize conditions such as "...(1) historical development, (2) political system, (3) political culture, (4) media freedom, (5) level of state control and regulation of media by the state, (6) media ownership and financing, (7) structure of media markets and patterns of information distribution, (8) orientation of media, (9) political/societal activity and parallelism of media, (10) journalism culture, and (11) journalistic professionalism" (p. 1). Other studies have coined these conditions more broadly as "media fields" (Benson, 2006; Couldry et al., 2010), which invites critical reflections on the complex and multilayered relationship between media forms and content. To put it in Benson's (2006) words, "it is just as much a mistake to locate journalistic (or any other form of specific cultural) autonomy on the side of a paternalistic as on the side of a privatizing state" (p. 197). This is because media quality also depends on the degree to which it is aligned with commercial interests, political parties, and ethnic group interests. Admittedly, journalistic culture, including the problems of bribery and corruption, must be examined closely if issues of impunity are to be dealt with in a meaningful manner.

\footnotetext{
${ }^{14}$ See reports by the Freedom House https://freedomhouse.org/report/freedom-press/2016/kenya. [Accessed 21 August 2018].
} 


\section{Political Impunity, "Policy Laundering", and "Critical Junctures"}

As argued in the previous sections, the shifts in media regulatory frameworks have largely been influenced by the changes in political environment. Over the years, the media sector has been the target of varying repressive bills, often justified on the grounds of national security and curbing irresponsible journalism. Although this is sometimes true, given the infiltration of corruption at the editorial levels (see Ireri, 2016; Kanyinga, 2014), the temporal survey of media regulations presented shows how the changes in political environments influence media regulations/policies across regimes. It is no surprise that there is a correlation between regime change and fluidity in media regulatory mechanisms.

Several studies specific to Kenya have documented the attempts by the state to implement controversial media bills often with little to no consultation with media owners' associations or the union of journalists (Oriare and Mshindi, 2008; Mitullah et al., 2015; Obonyo and Peel, 2012). For years, this was commonplace, as many media policies followed similar paths in the implementation process. If some of the proposed regulations/policies failed to materialize, it is probably due to the uproar by public and media activists. Examples of such attempts include the failed effort to establish a Task Force of Press in 1993 by the KANU government (Mbeke, 2008). This was followed by another attempt, in 1995, to introduce the Kenya Mass Media Commission Bill and Press Council of Kenya Bill, both of which failed due to pressure exerted on the government by media and human rights activists (Moggi and Tessier, 2001).

In an attempt to make sense of the shifts in media regulatory environment, some have argued that the creation of the Kenya Union of Journalists (KUJ) in 1998 and subsequent formation of the Media Council of Kenya (MCK) in 2002 (with operations in 2004) were largely due to the concerns that the state was increasingly seeking ways to stifle independent media operations (Mbeke, 2008). This is probably why the then MCK established the Code of Conduct and Practice of Journalism in Kenya to guide journalists through their news coverage. Despite these measures, the existence of independent media regulatory bodies has never stopped state-led attacks on journalists and their respective media organizations. The invasion of the Standard Media Group by state officials in 2006 and 2008 serves as an example (Onguny, 2016). The failed 2007 policy that required journalists to disclose their sources to the police forces and/or courts is another clear example of the state's attempts to establish policies limiting the exposure of acts of impunity (Ogola, 2015). For some, these challenges raise the question of whether the media should self-regulate, or the state should take active role in regulating the media (Obonyo and Peel, 2012). This, according to Obonyo and Peel (2012), remains the fundamental question that needs "to be negotiated between the media, those in power and the general public" (p. 139). Static constitutional amendments up until the 2010 constitution also highlight the commitment by successive governments to restrict reforms for political reasons.

Despite the changes in regime, the media environment has remained volatile. Under the first regime (1963-1978), Jomo Kenyatta made a handful of changes to the constitution to reflect Kenya's newly gained sovereignty (Faringer, 1991; 
Dixon, 1997; Okoth-Owiro, 1990). Meanwhile, under Daniel Moi (1978-2002), wide-ranging media policies were enacted with little public consultation (Helander, 2010; Ogola, 2011). During Kibaki's NARC government (20022013), media operations were still closely monitored by the state even though there was an exponential growth of commercial and independently-owned news media during this period (Ogola, 2015). Under Uhuru Kenyatta's Jubilee government (2013 to date), regulatory bodies have seen their powers amended (the 2013 Information and Communication Act) and a Tribunal (Multimedia Appeals Tribunal) established to address complaints against journalists and media houses (Media Policy Research Center, 2015). One emerging concern is that the Tribunal in question is not entirely independent of the state, raising serious questions with regard to fair hearing of journalists. For instance, a successful compliant may cost media houses up to USD \$20000 in fines, while individual journalists risk fines up to USD $\$ 5000^{15}$. Certainly, the hefty fines have become important deterrent mechanisms aimed at co-opting journalists and news editors into friendly coverage of the state and its operations (Zadock, 2013).

This does not mean journalistic practices, particularly the smaller news outlets, do not leave much to be desired in terms of professionalism and or ethnical conduct. Several studies on the relationship between the Kenyan media and state have highlighted the central role played by news editors and journalists in institutionalizing corruption and impunity by accepting bribes or "brown envelops" to "kill" certain stories (see Helander, 2010; Ireri, 2016; Kanyinga, 2014). While acknowledging the complex media-state relations, the argument advanced here is that successive regimes use regulations as a proxy to conveniently define what journalism is or should be. In turn, this impacts the manner in which the media covers issues of political impunity.

This fluidity in media regulations could be understood as a form of policy laundering, defined by Hosein $(2006,228)$ as "a practice where policy makers make use of other jurisdictions to further their goals, and in so doing circumvent national deliberative processes". According to Hosein (2006), two factors are indicative of a policy laundering environment. First, the "national consultative processes disappear or are weakened, as important policy decisions take place outside our traditional democratic institutions" (p. 228). Second, "policies are shaped by foreign interests and foreign processes" (p. 228). The notion of policy laundering captures the complex environment within which media regulations are established in Kenya. Whereas it is unquestionable that the challenges of national security have been on the rise (Onguny, 2020), it is increasingly becoming risky for journalists to expose scandals in government without political interference on news content, even though recent efforts against corruption are applauded. The coverage of opposition events during election cycles and police brutality have also been conveniently construed by the state as dissemination of "inciteful" information likely to cause public fear (Burke, 2018; Human Rights Watch, 2018).

\footnotetext{
${ }^{15}$ See reports by the Freedom House https://freedomhouse.org/report/freedom-press/2016/kenya. [Accessed 21 August 2018].
} 
As a result, some news anchors have resigned from mainstream media outlets due to arbitrary interference with news content ${ }^{16}$.

Overall, these cases show the linkages between regime change and the shifts in state-media relations. The longstanding question remains whether the Kenyan media is at a crossroads. To borrow from McChesney (2007), the answer lies in how "critical junctures" are used to bring about the desired change in an unravelling political environment. In writing about communication revolution, McChesney (2007) argued that media systems should take advantage of the "rare window of opportunity" provided by communication transformations (supported by digital revolution) to effect democratic media reforms. This is because such transformations provide "an unprecedented (rare window of opportunity in the next decade or two) to create a communication system that will be a powerful impetus (for) a more egalitarian, humane, sustainable, and creative (selfgoverning) society" (McChesney, 2007, p. ii and iii). It is the rarity in such opportunities that McChesney (2007) sees as "critical junctures" that should be seized upon in order to democratize media environments. According to him, media systems have become oligopolies that represent special interests rather than public interests. This is also because of the diminishing "corporate stranglehold over media system", increasingly challenged by citizens. Arguably, the biggest huddle for media systems remains the preservation of internet neutrality from government and corporate interference in the flow and/or circulation of information.

Although McChesney's work draws primarily on the American media system, its history, and political-economic realities, its relevance in understanding the challenges facing media systems stretches beyond the American context. Accordingly, "critical junctures" are crucial moments likely to bring about changes within a shifting media structure that, otherwise, would never be possible. Given the growth and expansion of mobile telephony and digital media spaces in Kenya (Onguny, 2014), local media systems hold the potential to effect changes that would see an increased public participation in the key debates affecting the country. This, of course, would only be possible if media actors (e.g., media owners, journalists, sponsors, activists, etc.) take active part in the ongoing discussions about referendum and possible constitutional change alongside the newly proposed Building Bridges Initiative (BBI).

\section{Conclusion}

This article discussed the interconnections between media regulations, statemedia relations, and the shifts in Kenya's media landscape. It argued that broad media regulations provide room to nurture an environment of self-censorship, particularly on matters of corruption and political impunity. The article adopted a political economic approach to assess the key temporal periods and how they have variably contributed to media regulatory framework, including media reach and concentration. It argued that these shifts influence journalistic practices, editorial independence, and the overall media landscape in Kenya. These discussions are

\footnotetext{
${ }^{16}$ Ibid.
} 
located in contexts of "policy laundering" to highlight the rapidly changing media and political environments.

Obviously, the regulations discussed here are not, by any means, exhaustive given the rapidly changing media landscape in Kenya. In fact, the ongoing discussions about the BBI and the looming referendum aimed at amending the current Constitution ahead of the 2022 elections are a clear indication of the continually shifting media environment. If seized as a "critical juncture", media organizations or unions could take an active role in negotiating media reforms in areas such as the protection and safety of journalists. Other reforms could target transparency and accountability of state bureaucrats such as pushing for live broadcast of parliamentary proceedings. Bringing clarity to broad clauses could also limit convenient interpretations that criminalize online political dissent or abusive attacks on independent political bloggers. This is because opinion pieces are part of a vibrant media environment contributing to the diversity of media content. Since the majority of media outlets are owned by politicians or influential businesspersons, revisiting media ownership patterns may be something worth pursuing.

Finally, and because journalists and news editors also play a central role in facilitating and/or institutionalizing political impunity, media owners can consider ways of incentivizing journalists/editors who uphold the highest journalistic ethics. Evidently, these are ambitious reforms whose degree of plausibility will highly depend on the political environment in place. Overall, if the patterns of media regulations described here are anything to go by, the new regime anticipated in 2022 is likely to bring with it new changes to media regulatory frameworks.

\section{References}

Bachelard, J. Y. (2010). The Anglo-leasing corruption scandal in Kenya: the politics of international and domestic pressures and counter-pressures. Review of African Political Economy, 37(124), 187-200.

BBC Media Action (2017). Strengthening accountability through media in Kenya. Retrieved from: http://dataportal.bbcmediaaction.org/site/assets/uploads/2017/07 /Kenya-Country-Report-2017.pdf. [Accessed 27 August 2018].

Benson, R. (2006). News media as a "journalistic field": what Bourdieu adds to new institutionalism, and vice versa. Political Communication, 23(2), 187-202.

Burke, J. (2018). Kenya's opposition swears in Raila Odinga as "people's president". The Guardian. Retrieved from: https://www.theguardian.com/world/2018/jan/30/kenyasopposition-to-swear-in-raila-odinga-as-peoples-president. [Accessed 28 August 2018].

Couldry, N., Livingstone, S., Markham, T. (2010). Media consumption and public engagement: beyond the presumption of attention. New York: Palgrave Macmillan.

Dixon, D. N. (1997). Press law debate in Kenya: ethics as political power. Journal of Mass Media Ethics, 12(3), 171-182.

Einashe, I. (2016). Kenya clamps down on journalists covering war on Al-Shabaab. The Guardian. Retrieved from: https://www.theguardian.com/world/2016/jun/27/kenyaclamps-down-on-journalists-covering-war-on-al-shabaab. [Accessed 28 August 2018]. 
Faringer, G. L. (1991). Press freedom in Africa. New York: Praeger.

Fuchs, C. (2010). Alternative media as critical media. European Journal of Social Theory, 13(2), 173-192.

Haugerud, A. (1995). The culture of politics in modern Kenya. Cambridge: Cambridge University Press.

Hosein, G. (2006). Policy laundering and other policy dynamics. In E. Haplpin (Ed.) Cyberwar, netwar and the revolution in military affairs (pp. 228-253). London: Palgrave Macmillan.

Helander, E. (2010). A critical view of the Kenyan media system through the perspective of the journalists. African Communication Research, 3(3), 521-542.

Hudson, D., Marquette, M. (n.d.). Mind the gaps: what's missing in political economy analysis and why it matters. Retrieved from: https://www.oecd.org/dac/accountableeffective-institutions/Governa nce\%20Notebook\%201.3\%20Hudson\%20et\%20al.pdf . [Accessed 12 May 2019].

Humans Rights Watch (2018). Kenya: Media barred from opposition event. Retrieved from: https://www.hrw.org/news/2018/01/30/kenya-media-barred-oppositionevent. [Accessed 28 August 2018].

Ireri, K. (2016). Do they preach water but drink wine? Examining "the corruption dragon" in Kenyan journalism. Journal of Media Ethics, 31(4), 245-59.

ITU (2017). Digital migration process in Kenya. Retrieved from: https://bit.ly/3fPzC Vv. [Accessed 28 August 2018].

Jarso, J. (2010). The media and the anti-corruption crusade in Kenya: weighing the achievements, challenges, and prospects. American University International Law Review, 26(1), 32-88.

Kanyinga, K. (2014). Democracy and political participation. Nairobi: Open Society Initiative for Eastern Africa.

Lohner, J., Banjac, S., Neverla, I. (2016). Mapping structural conditions of journalism in Kenya. Media Conflict and Democratization. Retrieved from: https://bit.ly/2W swHKy. [Accessed 21 August 2018].

Lynch, G. (2008). Courting the Kalenjin: The Failure of Dynasticism and the Strength of the ODM Wave in Kenya's Rift Valley Province. African Affairs, 107(429), 541568.

Lynch, G. (2014). Electing the "alliance of the accused": the success of the Jubilee Alliance in Kenya's Rift Valley. Journal of Eastern African Studies, 8(1), 93-114.

Mbeke, P. O. (2008). The media, legal, regulatory and policy environment in Kenya. Policy Briefing No. 1. BBC World Service Trust.

Mbeke, P. O., Ugangu, W., Okello-Orlale, R. (2010). The media we want. The Kenya media vulnerabilities study. Friedrich Ebert Stiftung (FES). Retrieved from: https://library.fes.de/pdf-files/bueros/kenia/07887.pdf. [Accessed 10 January 2019].

McChesney, R. (2007). Communication revolution: critical junctures and the future of media. New York: The New Press.

Media Policy Research Center (2015). State of the media in Kenya 2014: uncertainty, resistance and change. Nairobi: Media Policy Research Center.

Mitullah, W. V., Mudhai O. F., Mwangi, S. (2015). Background paper: politics and interactive media in Kenya. Politics and Interactive Media in Africa. Retrieved from: https://core.ac.uk/reader/77408486. [Accessed 10 January 2019].

Moggi, P., Tessier, R. (2001). Media status report: Kenya. Nairobi: Groupe de Recherche et d'Échanges Technologiques (GRET).

Mueller, S. D. (2014). Kenya and the International Criminal Court (ICC). Politics, the election and the law. Journal of Eastern African Studies, 8(1), 25-42. 
Muhatia, A. (2017). Government to seek lower ad rates from media houses. The Star. Retrieved from: https://www.the-star.co.ke/news/2017/09/06/governm ent-toseek-lower-ad-rates-from-media-houses_c1630127. [Accessed 28 August 2018].

Obonyo, L. (2003). The background of Kenya press. In A. Quick (Ed.) World press encyclopedia: a survey of press systems worldwide (pp. 529-539). New York: Gale Group.

Obonyo, L., Peel, C. (2012). Media regulation in emerging democracies: The example of Kenya's hybrid model. African Communication Research, 5(2), 139-159.

Ochilo, J. P. (1993). Press freedom and the role of the media in Kenya. Africa Media Review, 7(3), 19-33.

Ogenga, F. (2013). The media coverage of the Hague trials and the construction of new ethnic subjectivities in Kenya. African Conflict \& Peacebuilding Review, 3(1), 158174.

Ogbondah, C. (1994). Press freedom and political development in Africa. Africa Media Review, 8(3), 20-31.

Ogola, G. (2011). The political economy of the media in Kenya: from Kenyatta's nation-building press to Kibaki's local-language FM radio. Africa Today, 57(3), $77-95$.

Ogola, G. (2015). African journalism: a journey of failures and triumphs. African Journalism Studies, 36(1), 93-102.

Okoth, A. (2016). Increasing the oversite role in the usage of public funds in Kenya. Maryland: John Hopkins University.

Okoth-Owiro, A. (1990). Law and mass media in Kenya. Africa Media Review, 4(1), 14 26.

Onguny, P. (2014). Potential of mobile media as a space for political deliberation in subSaharan Africa. Rhodes Journalism Review, 34(0), 71-74.

Onguny, P. (2016). Indigenous language radios in Kenya and the negotiation of intergroup relations during conflict processes. In A. Salawu, M. Chibita (Eds.) Indigenous language media, language politics and democracy in Africa (pp. 151-181). London: Palgrave Macmillan.

Onguny, P. (2020). Framing the war on terror in Kenya: perspectives on the attacks at Westgate Mall and Garissa University. African Journal of Terrorism \& Insurgency Research, 1(1), 77-101.

Oriare P. M., Mshindi, T. (2008). Kenya media sector analysis report. Nairobi: Canadian International Development Agency (CIDA).

Posetti, J., Matthews, A. (2018). A short guide to the history of fake news and disinformation: a new ICFJ learning module. International Center for Journalists. Retrieved from: https://bit.ly/3fCCO6D. [Accessed 10 January 2019].

Robertson, N., Verjee, Z., Smith-Spark, L. (2013). Kenya mall attack video fuels army looting claims. CNN. Retrieved from: https://www.cnn.com/2013/10/22/world/ africa/kenya-mall-attack-looting/index.html [Accessed 28 August 2018].

Schifrin, A. (2017). In the service of power: media capture and the threat to democracy. Washington: Center for International Media Assistance (CIMA).

Schmidt, C., Deselaers, J. (2015). Kenya's media landscape - everyday constraints and structural challenges. In C. Schmidt (Ed.) Kenya's media landscape: a success story with serious structural challenges (pp. 10-26). Leipzig: VISTAS Verlag.

Shilaho, W. (2013). Old Wine in New Skins: Kenya's 2013 elections and the triumph of the ancien régime. Journal of African Elections, 12(3), 89-119.

Shilaho, W. K. (2018). The International Criminal Court (ICC), impunity, and the elusive justice in Kenya. In political power and tribalism in Kenya (pp. 143-163). Cham: Palgrave Macmillan. 
Somerville, K. (2012). Kenya: political violence, the media and the role of vernacular radio stations. In Radio propaganda and the broadcasting of hatred (pp. 208-237). London: Palgrave Macmillan.

Wasserman, H. (2020). Fake news from Africa: panics, politics and paradigms. Journalism, $21(1), 3-16$.

Widner, J. A. (1992). The rise of a party-state in Kenya: from "Harambee!" to "Nyayo!". Berkeley: University of California.

Zadock, A. (2013). Westgate: Kimaiyo now threatens journalists. Daily Nation. Retrieved from: https://www.nation.co.ke/news/Reporters-face-arrest-for-exposing-Westgatelooting/1056-2044972-fq7ogxz/index.html. [Accessed 28 August 2018]. 